


\section{Doorzaaien met Engels raaigras ter vervanging van ruw beemdgras in grasland op kleigrond}

Herman de Boer

Henk Schilder

Dit onderzoek is uitgevoerd door Wageningen Livestock Research en gefinancierd door het ministerie van LNV en het bedrijfsleven (www.ruwvoerenbodem.nl) 
De Boer, H.C., Schilder, H., 2021. Doorzaaien met Engels raaigras ter vervanging van ruw beemdgras in grasland op kleigrond. Wageningen Livestock Research, Rapport 1354.

Dit rapport is gratis te downloaden op https://doi.org/10.18174/562083 of op www.wur.nl/livestock-research (onder Wageningen Livestock Research publicaties).

\section{(cc) BY-NC}

Dit werk valt onder een Creative Commons Naamsvermelding-Niet Commercieel 4.0 Internationaallicentie.

(C) Wageningen Livestock Research, onderdeel van Stichting Wageningen Research, 2022 De gebruiker mag het werk kopiëren, verspreiden en doorgeven en afgeleide werken maken. Materiaal van derden waarvan in het werk gebruik is gemaakt en waarop intellectuele eigendomsrechten berusten, mogen niet zonder voorafgaande toestemming van derden gebruikt worden. De gebruiker dient bij het werk de door de maker of de licentiegever aangegeven naam te vermelden, maar niet zodanig dat de indruk gewekt wordt dat zij daarmee instemmen met het werk van de gebruiker of het gebruik van het werk. De gebruiker mag het werk niet voor commerciële doeleinden gebruiken.

Wageningen Livestock Research aanvaardt geen aansprakelijkheid voor eventuele schade voortvloeiend uit het gebruik van de resultaten van dit onderzoek of de toepassing van de adviezen.

Wageningen Livestock Research is NEN-EN-ISO 9001:2015 gecertificeerd.

Op al onze onderzoeksopdrachten zijn de Algemene Voorwaarden van de Animal Sciences Group van toepassing. Deze zijn gedeponeerd bij de Arrondissementsrechtbank Zwolle. 


\section{Inhoud}

$\begin{array}{ll}\text { Samenvatting } & 5\end{array}$

1

Inleiding

$\begin{array}{ll}\text { Materiaal \& methoden } & 8\end{array}$

$\begin{array}{lll}2.1 & \text { Proefopzet } & 8\end{array}$

2.2 Proefvelden $\quad 8$

2.3 Proefuitvoer 9

2.3.1 Voorbehandeling 9

$\begin{array}{ll}2.3 .2 \text { Doorzaaien } & 10\end{array}$

$\begin{array}{ll}2.3 .3 \text { Bemesting } & 10\end{array}$

2.3.4 Onkruidbestrijding 10

$\begin{array}{ll}2.3 .5 \text { Waarnemingen } & 10\end{array}$

$\begin{array}{ll}\text { 2.3.6 Statistische analyse } & 12\end{array}$

3

$\begin{array}{ll}\text { Resultaten } & 14\end{array}$

$\begin{array}{lll}3.1 & \text { Doorzaaiomstandigheden } & 14\end{array}$

3.2 Aantal kiemplanten $\quad 16$

$\begin{array}{lll}3.3 & \text { Muizenschade } & 18\end{array}$

$\begin{array}{ll}3.4 & \text { Botanische samenstelling }\end{array}$

$\begin{array}{lll}3.5 & \text { Grasopbrengst } & 28\end{array}$

$\begin{array}{lll}3.6 & \text { Voederwaarde } & 30\end{array}$

4

$\begin{array}{ll}\text { Discussie } & 34\end{array}$

4.1 Aantal kiemplanten 34

4.2 Botanische samenstelling $\quad 35$

$\begin{array}{lll}4.3 & \text { Grasopbrengst } & 37\end{array}$

$\begin{array}{lll}4.4 & \text { Voederwaarde } & 37\end{array}$

$\begin{array}{lll}4.5 & \text { Muizenschade } & 38\end{array}$

$\begin{array}{ll}\text { Conclusies } & 39\end{array}$

$\begin{array}{ll}\text { Betekenis voor de praktijk } & 41\end{array}$

Dankwoord $\quad 42$

$\begin{array}{ll}\text { Referenties } & 43\end{array}$

$\begin{array}{ll}\text { Bijlage } & 44\end{array}$ 



\section{Samenvatting}

Met doorzaaien van blijvend grasland kan herinzaai mogelijk worden vermeden. Vanaf de zomer van 2016 tot het voorjaar van 2021 is veldonderzoek uitgevoerd om vast te stellen welke effecten doorzaai met Engels raaigras (Lolium perenne L.) heeft op de botanische samenstelling, opbrengst, en voederwaarde van blijvend grasland met een voldoende dichte zode. De hypothese was dat doorzaai het aandeel Engels raaigras zou verhogen op percelen met een laag aandeel en zou handhaven op percelen met een hoog aandeel. Het onderzoek werd uitgevoerd op twee percelen met een 'slechte' botanische samenstelling, twee percelen met een 'matige' samenstelling, en een perceel met een 'goede' samenstelling. Het matig gewaardeerde ruw beemdgras (Poa trivialis L.) was na Engels raaigras de meest dominante grassoort. Voorafgaande aan het doorzaaien werd de zode behandeld om ongewenste soorten te verwijderen en de openheid te vergroten. Voorbehandelingen waren combinaties van kort afmaaien $(2 \mathrm{~cm})$, wiedeggen, en chemische bestrijding van ruw beemdgras. De behandelingen werden uitgevoerd in alleen het najaar van 2016, in het najaar van 2016 en 2017, en in het najaar van 2016, 2017, 2018, en 2019. De botanische samenstelling en grasopbrengst werden de eerste drie jaar op alle percelen gemeten en in 2020 op alleen twee percelen, met aanvullend ook bepaling van de voederwaarde.

De resultaten laten zien dat na doorzaaien het vochtgehalte in de toplaag van de grond doorslaggevend is voor het aantal kiemplanten: in 2016 bleken de omstandigheden te droog en in 2017 te nat voor een geslaagde doorzaai. Doorzaai in 2016, 2017, 2018, of 2019 gaf respectievelijk gemiddeld 28, 30, 84, en 418 kiemplanten Engels raaigras per $\mathrm{m}^{2}$. Het grote aantal kiemplanten in 2019 leek vooral het gevolg van het extra rollen van de doorgezaaide veldjes, waardoor de zaaisneden volledig sloten en de vochtvoorziening van de zaden maximaal was. Doorzaai in 2016 of 2017 had geen effect op het aandeel Engels raaigras in de volgende jaren. Doorzaai in 2018 gaf in de zomer van 2019 op vier van de vijf percelen een 5 tot 7 procentpunt (pp.) hoger aandeel Engels raaigras. Doorzaai in 2019 had geen effect op het aandeel Engels raaigras in 2020, waarschijnlijk vanwege de zware muizenvraat in de voorgaande winter. Het effect van doorzaaien in 2018 leek echter nog grotendeels aanwezig.

In geen van de proefjaren had doorzaaien effect op de grasopbrengst van volgende jaren. Wel waren er positieve effecten van voorbehandeling op de grasopbrengst in 2019 en 2020 en op de voederwaarde in 2020. Voorbehandeling in 2018 gaf in 2019 een 5-9\% hogere grasopbrengst, en voorbehandeling in 2018 en 2019 gaf in 2020 een 6-8\% hogere grasopbrengst. Voorbehandeling in 2019 had in 2020 geen effect op de verteerbaarheid van het gras, maar gaf een $5 \%$ lager eiwitgehalte (vanwege een hogere opbrengst) en een 8\% hoger suikergehalte. Voorbehandeling in 2016 en 2017 gaf in 2020 een 13\% hogere jaaropbrengst suiker. De positieve effecten van voorbehandeling zijn waarschijnlijk het gevolg van een beperking van de beschutting voor de muizen, waardoor deze op voorbehandelde veldjes minder aanwezig waren en minder schade veroorzaakten. Hierdoor nam het aandeel Engels raaigras minder af (perceel 2) en was, als gevolg van minder schade aan stoppels en wortels, de opbrengst het volgende voorjaar hoger.

Wiedeggen bleek voldoende effectief om ruw beemdgras te bestrijden, en aanvullende chemische bestrijding had weinig effect. De door eggen gecreëerde ruimte werd alleen ingenomen door Engels raaigras als ook werd doorgezaaid, en anders opnieuw door ruw beemdgras. Op onbehandelde veldjes nam bij drie van de vijf percelen over de eerste drie jaar het aandeel Engels raaigras toe, met 7 tot 11 pp. Hieruit blijkt dat het aandeel Engels raaigras ook kan worden verhoogd door het type beheer, in dit geval alleen bemesten met kunstmest, alleen maaien, en zwaar maaien van de eerste snede. Geconcludeerd wordt dat bij keuze van geschikte doorzaai-omstandigheden het aandeel Engels raaigras in de zode duidelijk kan worden verhoogd wanneer ruw beemdgras de te vervangen grassoort is, maar dat deze verhoging niet zondermeer zal resulteren in een toename van grasopbrengst en/of voederwaarde van grasland op kleigrond. 


\section{$1 \quad$ Inleiding}

De botanische samenstelling van nieuw ingezaaid productiegrasland kan na een aantal jaren weer gaan veranderen. Oorspronkelijk gezaaide grassoorten worden geleidelijk vervangen door andere, minder gewenste of ongewenste plantensoorten (Sikkema, 1997). Wanneer het aandeel gewenste soorten te veel is afgenomen, wordt de bestaande graszode omgeploegd en wordt er opnieuw ingezaaid met gewenste soorten.

Ploegen en herinzaai van bestaand grasland is onwenselijk, vanwege te maken kosten, verlies van organische stof (OS), verlies van nutriënten, en tijdelijke extra belasting van het milieu door extra uitspoeling van nitraat en extra emissies van broeikasgassen (Drewer et al., 2017; Necpálová et al., 2014; Shepherd et al., 2001). Daarnaast sterft als gevolg van ploegen een deel van de bodemflora en -fauna af en heeft deze tijd nodig om weer te herstellen (Van Eekeren et al., 2008).

Een logische aanpak om herinzaai te vermijden is het voorkomen van botanische verslechtering. Verslechtering kan het gevolg zijn van bijvoorbeeld droogte, vraatschade, verzuring van de grond, vernatting of verdichting van de grond, of te intensief maaien of weiden. Plantensoorten die gevoeliger zijn voor dergelijke veranderingen nemen in aantal af en worden vervangen door minder gevoelige soorten of soorten die open plekken sneller kunnen bezetten. Een verslechtering van de botanische samenstelling kan deels worden tegengegaan door zorgvuldig graslandbeheer. Droogteschade kan worden beperkt door regelmatig te beregenen, verzuring door onderhoudsbekalking, verdichting door een verstandig gebruik van (zware) machines, en vernatting door de aanleg en het tijdige onderhoud van drainage. Beweiden kan zorgen voor een dichtere zode en tijdig maaien voorkomt beschadiging van de zode en het ontstaan van open plekken, waar ongewenste soorten zich kunnen vestigen en uitbreiden.

Een mogelijk geschikte aanvullende onderhoudsmaatregel is regelmatige doorzaai van het grasland met gewenste soorten, om op die manier hun aandeel in de zode stabiel te houden of te laten toenemen. Uit de praktijk komen positieve geluiden over doorzaaien; bij regelmatige doorzaai met Engels raaigras zou het aandeel van deze soort in de zode geleidelijk toenemen. Er zijn echter ook melkveehouders die weinig of geen verbetering ervaren en kritisch zijn over de effectiviteit van doorzaaien.

Een complicerende factor bij de beoordeling van ervaringen is dat de term 'doorzaaien' in de praktijk voor verschillende situaties wordt gebruikt, zowel voor het doorzaaien van een zode met een goede bezetting, een zode met grote open plekken, en zelfs een doodgespoten zode. De laatste twee situaties betreffen eigenlijk vormen van herinzaai, plaatselijk of volvelds.

De effectiviteit van het doorzaaien van een intacte graszode met een goede bodembedekking is weinig onderzocht. Uitgevoerde experimenten waren meestal beperkt van opzet en hadden een relatief korte looptijd. Er is daarom behoefte aan experimenteel onderzoek om vast te stellen of door regelmatige doorzaai van een bestaande graszode, met een goede bezetting, het aandeel Engels raaigras kan worden gehandhaafd of verhoogd.

Daarom is in de periode 2016 t/m 2020 een vierjarig veldonderzoek uitgevoerd. De hypothese bij dit onderzoek was dat regelmatige doorzaai van een bestaande graszode met Engels raaigras het aandeel Engels raaigras kan verhogen op percelen met een laag aandeel en kan handhaven op percelen met een hoog aandeel. De opzet, uitvoering, resultaten, en interpretatie van dit onderzoek zijn in het voorliggende rapport beschreven. 


\section{Materiaal \& methoden}

\subsection{Proefopzet}

Het doel van het onderzoek was het meten van het effect van herhaald doorzaaien met Engels raaigras (Lolium perenne L.) op de botanische samenstelling, opbrengst, en voederwaarde van grasland met een goede bezetting. Het onderzoek werd uitgevoerd op vijf percelen grasland met verschillende botanische samenstelling: twee percelen met een als 'slecht' beoordeelde samenstelling, twee percelen met een 'matige' samenstelling, en één perceel met een 'goede' samenstelling (Tabel 1 Tabel 15). Over een periode van ruim drie jaar werd tot vier keer in het najaar doorgezaaid: alleen in het najaar van 2016, in het najaar van 2016 en 2017, en in het najaar van 2016, 2017, 2018, en 2019. Voorafgaande aan het doorzaaien werd de zode op verschillende manieren voorbehandeld, om ongewenste soorten te verwijderen en de openheid te vergroten. Wel of niet doorzaaien werd daarbij gecombineerd met wel of niet kort afmaaien, eggen, en wel of geen chemische bestrijding van het veel voorkomende 'matige' ruw beemdgras (Poa trivialis L.). Dit gaf zes behandelingen:
1) geen behandeling, controle;
2) kort afmaaien + eggen + spuiten in 2016, 2017, 2018, en 2019;
$3)$ kort afmaaien + eggen + spuiten + doorzaaien in 2016;
4) kort afmaaien + eggen + spuiten + doorzaaien in 2016 en 2017;
5) kort afmaaien + eggen + spuiten + doorzaaien in 2016, 2017, 2018, en 2019;
6) kort afmaaien + eggen + doorzaaien in 2016, 2017, 2018, en 2019.

De behandelingen werden op ieder perceel drie keer herhaald, in drie gerandomiseerde blokken, op zes veldjes $(10 * 2,5 \mathrm{~m}$ ) per blok, 18 veldjes per perceel, en 90 veldjes in totaal.

\subsection{Proefvelden}

De vijf percelen grasland lagen op kleigrond in Noord-Nederland, drie percelen op proefbedrijf Dairy Campus en twee percelen op een melkveebedrijf in de buurt ( $9 \mathrm{~km}$ afstand hemelsbreed). Een overzicht van een aantal relevante gegevens van deze percelen is gegeven in Tabel 1 .

Tabel 1 Locatiegegevens, grondsamenstelling $(0-10 \mathrm{~cm})$, en waardering van botanische samenstelling van de vijf percelen grasland bij start van het onderzoek.

\begin{tabular}{|c|c|c|c|c|c|}
\hline \multirow[t]{2}{*}{ Parameter } & \multicolumn{5}{|c|}{ Perceelnummer } \\
\hline & 1 & 2 & 3 & 4 & 5 \\
\hline Perceelnaam/code & Werpsterwei & Over Erf & B2 & A6 & E1 \\
\hline \multirow[t]{2}{*}{ GPS-coördinaten } & 53.165482 & 53.169722 & 53.178311 & 53.173667 & 53.181055 \\
\hline & 5.624260 & 5.633358 & 5.759830 & 5.762928 & 5.750279 \\
\hline Grondwatertrap & $\mathrm{V}$ & $\mathrm{V}$ & III & III & $\mathrm{V}$ \\
\hline Botanische samenstelling ${ }^{1)}$ & 'slecht' & 'matig' & 'matig' & 'slecht' & 'goed' \\
\hline Leeftijd (jaren) & $>30$ & 39 & $>15$ & $>15$ & 1 \\
\hline \multicolumn{6}{|l|}{ Grondsamenstelling ${ }^{2)}$} \\
\hline Klei (\%) & 28 & 26 & 35 & 40 & 39 \\
\hline Silt (\%) & 47 & 43 & 39 & 38 & 38 \\
\hline Zand (\%) & 14 & 19 & 12 & 9 & 14 \\
\hline $\mathrm{pH}-\mathrm{KCl}(-)$ & 6,1 & 6,7 & 6,1 & 6,6 & 6,9 \\
\hline OS (\%) & 10,5 & 11,7 & 13,5 & 12,8 & 8,3 \\
\hline$N$-totaal $\left(m g ~ k g^{-1}\right)$ & 6390 & 6180 & 6910 & 6810 & 4430 \\
\hline C-totaal (\%) & 5,5 & 6,5 & 6,9 & 6,8 & 4,3 \\
\hline$C / N$-verhouding (-) & 8,6 & 10,5 & 10,0 & 10,0 & 9,7 \\
\hline
\end{tabular}

1) Beoordeeld op basis van het aanwezige aandeel gewenste grassen en kruiden op 30 augustus 2016 (Tabel 15)

2) In droge grond, gemeten door Eurofins Agro (nat-chemisch) in grondmonsters genomen op 24 oktober 2016 


\subsection{Proefuitvoer}

\subsubsection{Voorbehandeling}

Behandeling startte ieder jaar na het maaien van de vierde snede, eind augustus. In het eerste jaar van de proef (2016) werden na het maaien de proefvelden uitgezet en de veldjesgrenzen gemarkeerd. Na de eerste botanische kartering werden de relevante veldjes gespoten tegen ruw beemdgras, met $1200 \mathrm{ml} \mathrm{ha}^{-1}$ Puma SW (Bayer CropScience, Leverkusen, Duitsland) bij een waterverbruik van $400 \mathrm{~L}$ $\mathrm{ha}^{-1}$. Puma SW werd toegepast volgens het toegestane gebruik in de akkerbouwmatige grasteelt, waarbij voorkomen wordt dat het geoogste gras in de voedselketen komt. De bespuiting werd in de opeenvolgende jaren uitgevoerd op respectievelijk 2 september, 21 september, 15 september, en 28 augustus. Twee weken na bespuiting werden de veldjes met eg- of doorzaaibehandeling kort afgemaaid, in 2016 op 5-6 cm hoogte en in 2017, 2018, en 2019 op $2 \mathrm{~cm}$ hoogte. Het maaisel werd aan weerszijden buiten ieder proefveld gelegd om daar te verteren. Na het kort afmaaien werden de relevante veldjes geëgd met een 2,5 m brede wiedeg, uitgevoerd met drie rijen dubbele tanden ( $\varnothing 9$ $\mathrm{mm}$ ) (Foto 1). Deze rijen waren verspringend achter elkaar geplaatst (bij iedere volgende rij waren de tandensets geplaatst in het midden van twee sets op de vorige rij). Afstanden waren $45 \mathrm{~cm}$ tussen de rijen, $28 \mathrm{~cm}$ tussen de tandensets, en 12-14 cm tussen de tanden per set. Elk veldje werd drie keer geëgd. Het dode materiaal dat bij het eggen uit de zode kwam (Foto 2) werd naar weerszijden buiten het proefveld geharkt om daar te verteren. In 2017 werd niet geëgd omdat de grond daarvoor te nat was. Eggen werd in de opeenvolgende jaren uitgevoerd op respectievelijk 14 september 2016, 1 oktober 2018, en 16 september 2019.

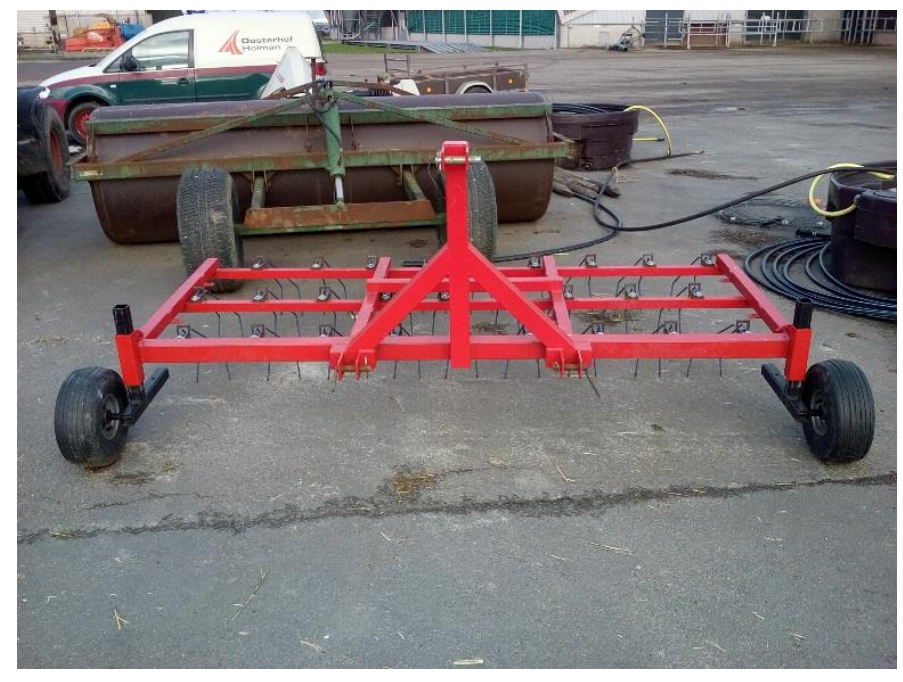

Foto 1 Wiedeg gebruikt in het doorzaaionderzoek.

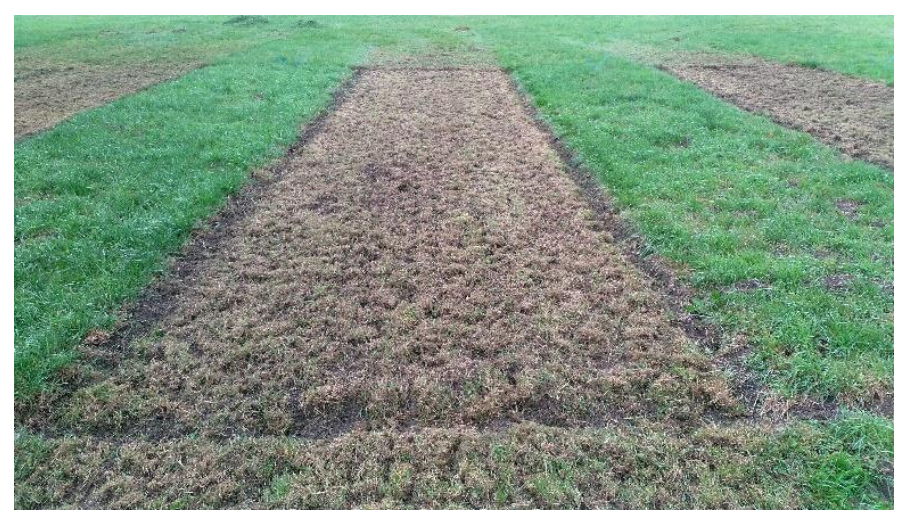

Foto 2 Dood materiaal uit de zode na wiedeggen van perceel 4 op 16 september 2019. 


\subsubsection{Doorzaaien}

Na eggen werd op de relevante veldjes $25 \mathrm{~kg} \mathrm{ha}^{-1}$ tetraploïd Engels raaigras (cv. Dromara) doorgezaaid, met een 2,5 meter brede Vredo Agri doorzaaimachine, op een diepte van 1 tot 1,5 cm. In 2016, 2017, en 2018 was dit een machine met luchtondersteuning (Agri Air), in 2019 een machine zonder luchtondersteuning. In 2016 en 2019 was de machine uitgerust met een gladde aandrukrol en in 2017 en 2018 met een Cambridgerol. In 2019 werden alle doorgezaaide veldjes na het doorzaaien nogmaals gerold, waarbij de aandrukrol verder naar beneden was ingesteld. Door dit extra rollen werden de zaaisneden, die in voorgaande jaren deels open waren blijven staan, geheel dichtgeduwd. Doorzaaien werd in de vier opeenvolgende jaren uitgevoerd op respectievelijk 15 september, 4 oktober, 3 oktober, en 18 september. In 2018 werden de proefvelden, vanwege aanhoudende droogte na het doorzaaien, twee keer beregend, met $10 \mathrm{~mm}$ water per keer, met behulp van een drijfmesttank met ketsplaat, op respectievelijk 11 en 16 oktober.

\subsubsection{Bemesting}

De proefveldjes werden per volledig groeiseizoen vier tot vijf keer gemaaid en bemest met $N, P$, en $K$. In 2017, 2018, 2019, en 2020 ontvingen de veldjes zonder doorzaai een N-bemesting voor de vijf sneden van respectievelijk 100,80, 70, 50 en $40 \mathrm{~kg} \mathrm{~N} \mathrm{ha}^{-1}$, voor een totale jaarbemesting van $340 \mathrm{~kg}$ $\mathrm{N} \mathrm{ha}^{-1}$. Door te zaaien veldjes kregen, om de hergroei te vertragen, geen $\mathrm{N}$-bemesting voor de vijfde snede in het jaar van doorzaai en ontvingen dan op jaarbasis $300 \mathrm{~kg} \mathrm{~N} \mathrm{ha}^{-1}$. In 2016 werd de Nbemesting voor de vijfde snede op alle veldjes achterwege gelaten. In 2018, 2019, en 2020 werd alle $\mathrm{N}$ bemesting toegediend in de vorm van kunstmest KAS $(27 \% \mathrm{~N})$. In 2017 werd de eerste snede van percelen 1 en 2 bemest met 30 ton runderdrijfmest ha ${ }^{-1}$, toegediend met een zodebemester. De berekende werkzame $\mathrm{N}$ uit deze drijfmest voor de eerste vier sneden werd in mindering gebracht op de totale $\mathrm{N}$-gift, en de rest van de $\mathrm{N}$ werd toegediend met KAS. De werkzame $\mathrm{N}$ uit de drijfmest werd berekend met behulp van het gemiddelde $\mathrm{N}$-gehalte in runderdrijfmest en de werkingscoëfficiënten uit de Bemestingsadviesbasis (Anonymus, 2016).

Ieder groeiseizoen werden de eerste en derde snede ieder bemest met $26 \mathrm{~kg} \mathrm{P}^{-1}$ uit tripelsuperfosfaat (20\% P) en $124 \mathrm{~kg} \mathrm{~K} \mathrm{ha}^{-1}$ uit KCl $(60 \% \mathrm{~K})$, om de jaarlijkse P- en K-onttrekking door het gras te compenseren. Percelen met toediening van runderdrijfmest in 2017 kregen geen Pen K-bemesting met kunstmest voor de eerste snede, omdat deze bemesting al was ingevuld met de drijfmest. De N-bemesting voor de vijfde snede werd per veldje met de hand gestrooid door een medewerker van proefbedrijf Dairy Campus. Alle andere bemesting werd toegediend met een praktijkstrooier, in de lengterichting van het proefveld. Kunstmest werd doorgaans binnen enkele dagen na het maaien van de vorige snede gestrooid.

\subsubsection{Onkruidbestrijding}

Perceel 4 werd vanaf 4 augustus 2016 meerdere keren gespoten met Primstar (Dow AgroSciences, Indianapolis, USA) tegen de dominant aanwezige paardenbloem (Taraxacum officinale F.H. Wigg). De laatste bespuiting was op 12 mei 2017, en op 6 juni was de paardenbloem vrijwel verdwenen. Op perceel 1 werd op 4 augustus 2016 ridderzuring (Rumex obtusifolius L.) bestreden door aanwezige planten individueel te bespuiten met Primstar. Op perceel 2 werden in 2020 tijdens de groei van de derde snede de op enkele veldjes aanwezige gekroesde melkdistels (Sonchus asper L.) handmatig zoveel mogelijk uit de zode verwijderd.

\subsubsection{Waarnemingen}

Weer

Neerslaggegevens werden overgenomen van weerstation Skrins en temperatuurgegevens van weerstation Leeuwarden (KNMI, De Bilt).

Grond

Waarnemingen aan de grond bestonden, vanaf 2017, uit een bepaling van het bodemvochtgehalte op het moment van doorzaaien. Per proefveld werden minimaal 30 steken genomen van laag 0-10 cm, in 
een zigzagpatroon over de lengterichting van het proefveld. De verzamelmonsters werden gewogen, 48 uur gedroogd bij $105^{\circ} \mathrm{C}$, en opnieuw gewogen, ter bepaling van het vochtgehalte.

\section{Gewas}

Waarnemingen aan het gewas bestonden uit het tellen van het aantal kiemplanten na doorzaaien, kartering van de botanische samenstelling van de zode, visueel schatten van muizenschade, en bepaling van de grasopbrengst en -voederwaarde.

Het aantal kiemplanten werd 29 tot 42 dagen na doorzaaien geteld, in een raster van $50 \times 50 \mathrm{~cm}$, op drie plaatsen op de diagonale lijn van ieder veldje. Kiemplanten van Engels raaigras zijn bij een aantal cultivars, waaronder Dromara, te onderscheiden van andere kiemplanten en spruiten door de aanwezigheid van een rode stengelvoet. Tellingen werden uitgevoerd op respectievelijk 26/27 oktober 2016, 6 november 2017, 1 november 2018, en 22 oktober 2019. In 2019 werd ook een vroege telling uitgevoerd, 17 dagen na doorzaai, op 5 oktober. Opkomstpercentages van het gezaaide zaad werden berekend op basis van de gezaaide hoeveelheid en het 1000-korrelgewicht, voor 2016 en 2018 op basis van het opgegeven 1000-korrelgewicht en voor 2017 en 2019 op basis van het gemiddelde 1000-korrelgewicht over 2016 en 2018 ( $2,75 \mathrm{~g})$.

De botanische samenstelling van de graszode werd twee keer per jaar gekarteerd: voorafgaande aan de uitvoer van behandelingen en ieder volgend voorjaar. Het doel van deze karteringen was om te bepalen hoe het aandeel van Engels raaigras en andere soorten werd beïnvloed door het doorzaaien. Karteringen werden uitgevoerd door een expert (Henk Schilder) en bestonden uit het per veldje visueel schatten van de totale relatieve bezetting (\%) door de graszode en het aandeel (\%) van iedere aangetroffen soort daarin (cf. methode Sikkema (1997); De Boer et al., 2018). Deze basiskarteringen (op alle veldjes) werden achtereenvolgens uitgevoerd op respectievelijk 30 augustus 2016, 23 mei/9 juni 2017, 11 september 2017, 10 april 2018, 14 september 2018, 12 april 2019, 14/16 augustus 2019, 10/11 april 2020, en 20/21 augustus 2020. In 2020 werden op percelen 2 en 3 aanvullende karteringen per snede uitgevoerd, respectievelijk op 15 juni, 15 juli, en 14 september. Het doel van deze extra karteringen was om te bepalen of en hoe het aandeel Engels raaigras tijdens het groeiseizoen veranderde. Percelen 2 en 3 werden gekozen omdat daar verschillen in aandeel Engels raaigras tussen behandelingen het grootst waren. In 2021 werd op percelen 2 en 3 nog een laatste kartering uitgevoerd, in het voorjaar (17 april), om te bepalen in hoeverre verschillen in aandeel Engels raaigras tussen behandelingen over de winter heen in stand waren gebleven. In 2018 en 2019 werd direct na doorzaaien de totale bezetting van behandelingen 5 of 6 opnieuw geschat. Het doel van deze extra waarneming was om te bepalen of er een afname was in de totale bezetting ( $\sim$ toename van openheid van de zode) als gevolg van voorbehandeling, en vervolgens of er een relatie was tussen de bezetting direct na behandeling en het aantal getelde kiemplanten. Deze extra waarneming werd uitgevoerd op respectievelijk 5 oktober 2018 en 18 september 2019.

Tijdens de proefperiode was er op de proefvelden sprake van schade door veldmuizen (Microtus arvalis), meestal al zichtbaar in het najaar en vervolgens toenemend tijdens de winter (Foto 3 en 4 ). De schade bleef beperkt in het voorjaar van 2017 en 2018, was hoger in het voorjaar van 2019, en was zwaar in het voorjaar van 2020. In 2020 werd op 6 maart de muizenschade per veldje visueel gescoord op een schaal van 1 tot 9 ( $1=$ veel schade, $9=$ weinig schade).

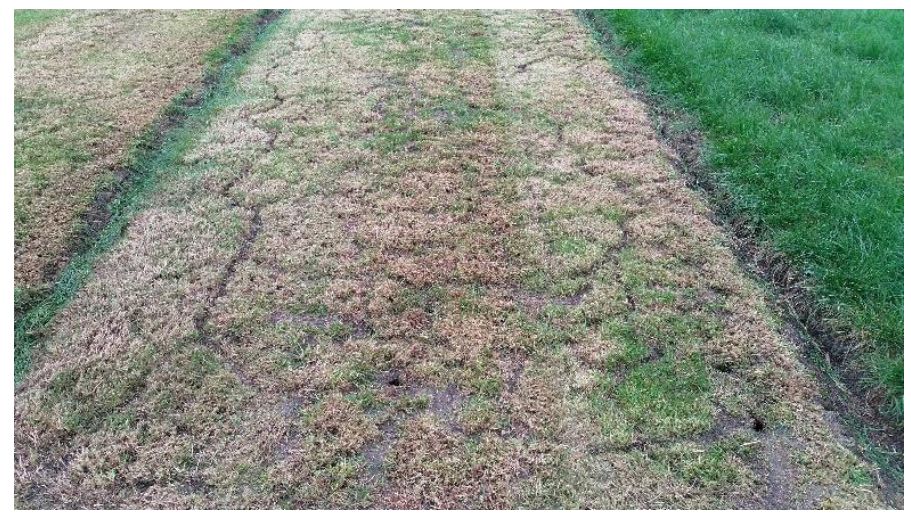

Foto 3 Muizenschade op perceel 4 na het kort afmaaien op 16 september 2019. 


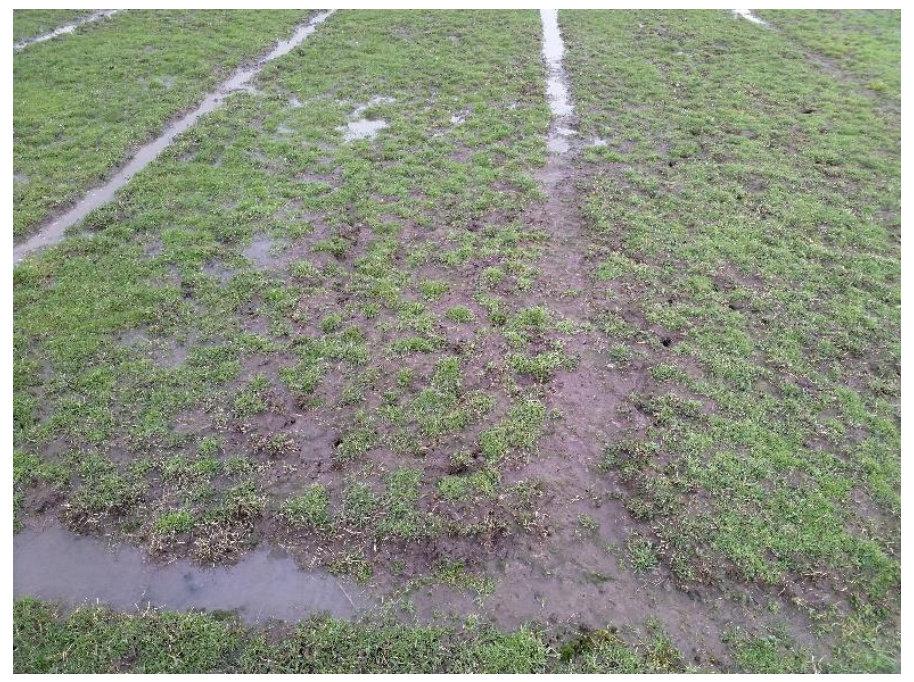

Foto 4

Muizenschade op perceel 4 op 10 februari 2020.

De grasopbrengst werd bepaald door het gras te maaien met een proefveldoogstmachine (J. Haldrup a/s, Løgstør, Denemarken), op een hoogte van $6 \mathrm{~cm}$ en over een breedte van $1,5 \mathrm{~m}$ in het midden van ieder veldje, voor een totaal geoogst oppervlak van $15 \mathrm{~m}^{2}$. Het geoogste gras werd gewogen en bemonsterd, de monsters vers gewogen, 48 uur gedroogd bij $70{ }^{\circ} \mathrm{C}$, en opnieuw gewogen ter bepaling van het drogestofgehalte en berekening van de drogestofopbrengst. In 2017, 2018, en 2019 werd de opbrengst van alle veldjes bepaald, in 2020 alleen van percelen 2 en 3. In 2020 werden de verzamelde grasmonsters na het drogen bewaard bij $4{ }^{\circ} \mathrm{C}$ en binnen enkele weken verstuurd naar Eurofins Agro (Wageningen) voor NIRS-analyse op verteerbaarheid van organische stof (VC-OS) en gehalte ruw as, ruw eiwit, en suiker.

\subsubsection{Statistische analyse}

Bij het aantal getelde kiemplanten Engels raaigras werden effecten van behandeling per afzonderlijk proefjaar geanalyseerd met behulp van de ANOVA-procedure in statistisch pakket Genstat (19e editie; VSNI, Hemel Hempstead, UK), met gebruik van de data van behandelingen 5 en 6 . Treatment structure was Perceel * Behandeling en Block structure was Blok. In 2019 werd een aanvullende analyse van het effect van tijdstip van tellen uitgevoerd. Treatment structure was Perceel * Behandeling * Tijdstip en Block structure was Blok/Veldnr/Tijdstip. Het effect van behandeling op de totale bezetting direct na doorzaaien (gemeten in 2018 en 2019) werd voor behandelingen 5 en 6 per afzonderlijk proefjaar geanalyseerd met behulp van de ANOVA-procedure. Treatment structure was Perceel * Behandeling * Tijdstip en Block structure was Blok/Veldnr/Tijdstip. Relaties tussen de totale bezetting direct na doorzaaien en het aantal getelde kiemplanten werden voor de data van behandelingen 5 en 6 geanalyseerd met behulp van de procedure voor lineaire regressie in statistisch pakket Genstat.

Bij de botanische kartering werd het effect van tijdstip van karteren (voorjaar of zomer) op het aandeel Engels raaigras per afzonderlijk proefjaar geanalyseerd met behulp van de ANOVA-procedure. Treatment structure was Perceel * Behandeling * Tijdstip en Block structure was Blok/Veldnr/Tijdstip. Effecten van behandelingen op de totale bezetting, het aandeel Engels raaigras, en het aandeel ruw beemdgras, allen gemeten tijdens de zomer, werden per afzonderlijk proefjaar geanalyseerd.

Treatment structure was Perceel * Behandeling en Block structure was Blok. Verschillen tussen percelen in gemiddeld aandeel Engels raaigras werden per afzonderlijk proefjaar weergegeven op basis van het hoofdeffect van Perceel. Verandering in aandelen van Engels raaigras en andere meest aanwezige soorten, tussen zomer 2016 en zomer 2019, tussen zomer 2016 en zomer 2020, of tussen zomer 2019 en voorjaar 2020, werden geanalyseerd voor de controleveldjes. Treatment structure was Perceel * Tijdstip en Block structure was Blok/Veldnr/Tijdstip. De scores van de muizenschade (voorjaar 2020) werden geanalyseerd met de ANOVA-procedure. Treatment structure was Perceel * Behandeling en Block structure was Blok. 
Grasopbrengsten werden per afzonderlijk proefjaar geanalyseerd met de REML-procedure voor herhaalde waarneming, met Veldnr. als Subjects en Snedenr. als Timepoints. Fixed model was Perceel * Behandeling * Snedenr., Random model was Blok, en het correlatiemodel was AR1 (Antedependence order 1). Per afzonderlijk jaar werden alle individuele snede-opbrengsten gezamenlijk geanalyseerd, de eerste vier sneden voor alle behandelingen en de vijf sneden voor alleen de behandelingen waarbij vijf sneden waren geoogst. In 2020 werden de opbrengst en voederwaardekenmerken van de vijf sneden gezamenlijk geanalyseerd met de bovenstaande REML-procedure, en aanvullend werd de jaaropbrengst geanalyseerd met de ANOVA-procedure. Voederwaardekenmerken werden voorafgaande aan de statistische analyse loggetransformeerd (LN), omdat in enkele situaties de residuen niveau-afhankelijk waren. 


\section{Resultaten}

\subsection{Doorzaaiomstandigheden}

\section{6}

In 2016 werd op 15 september doorgezaaid in een droge toplaag en onder droge omstandigheden. De insnijding door de zaaimachine was voldoende en het zaad werd goed verdeeld. Op de dag van doorzaaien had het 10 dagen niet geregend, en in de 15 dagen daarna viel er, in tegenstelling tot de weersverwachting, vrijwel geen neerslag (Fig. 1). De temperatuur was de eerste 14 dagen na het doorzaaien gemiddeld $16,1^{\circ} \mathrm{C}$.

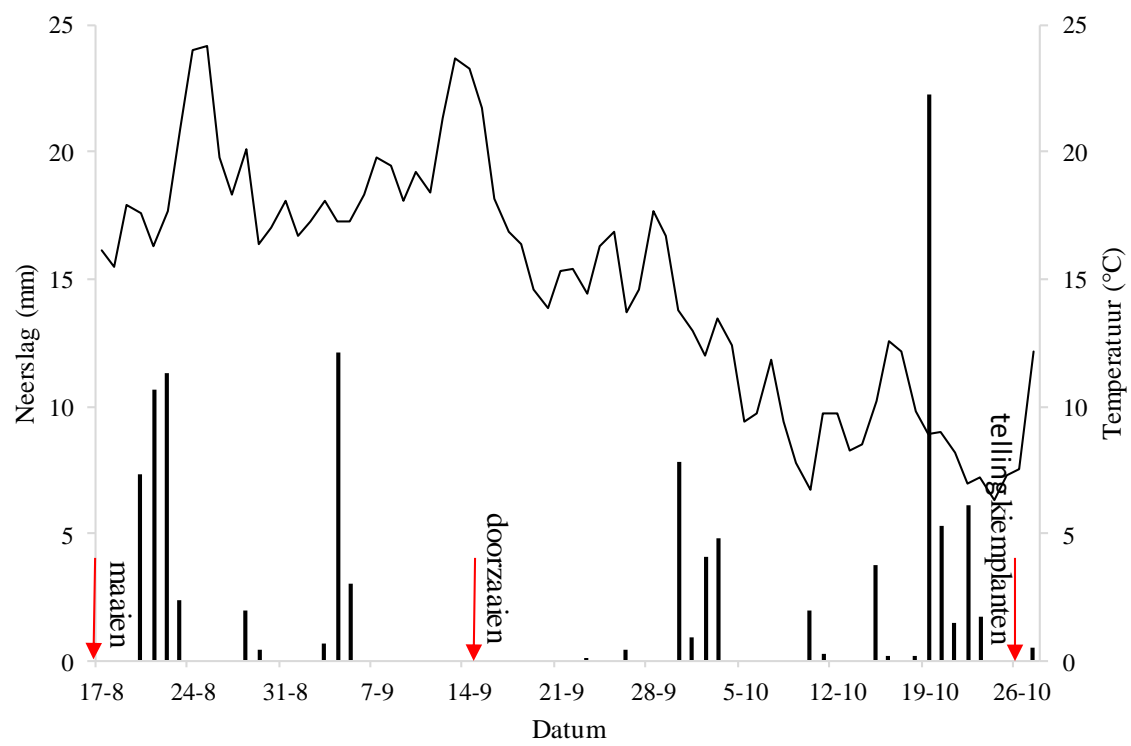

Figuur 1 Dagelijkse neerslag (kolommen, linker $y$-as) en gemiddelde temperatuur (lijn, rechter yas) in 2016 tussen het moment van maaien van de vierde snede en telling van de kiemplanten (gegevens KNMI-stations Skrins (neerslag) en Leeuwarden (temperatuur)).

2017

In 2017 werd op 4 oktober doorgezaaid in een natte toplaag (Tabel 2, Fig. 2). De mate van insporing werd beoordeeld als acceptabel. De machine sneed goed in grond maar het zaad leek minder regelmatig te worden verdeeld dan in 2016. Na het doorzaaien viel er regelmatig regen en bij opkomst van de eerste kiemplanten (rond 21 oktober) stonden er plasjes water op enkele percelen. De temperatuur was de eerste 14 dagen na het doorzaaien gemiddeld $13,6^{\circ} \mathrm{C}$.

Tabel 2 Vochtgehalte (\%) in bodemlaag $0-10 \mathrm{~cm}$ van de vijf percelen rond het moment van doorzaaien in 2017, 2018, en 2019.

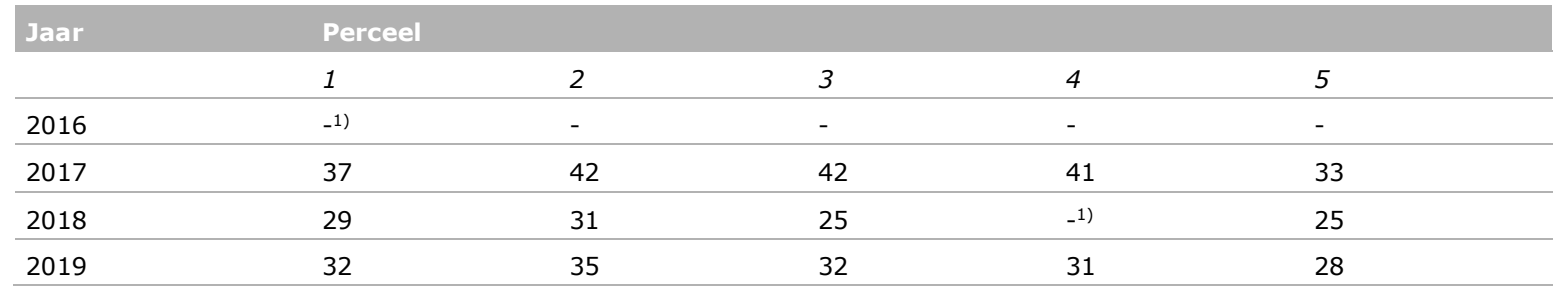

1) niet bepaald 


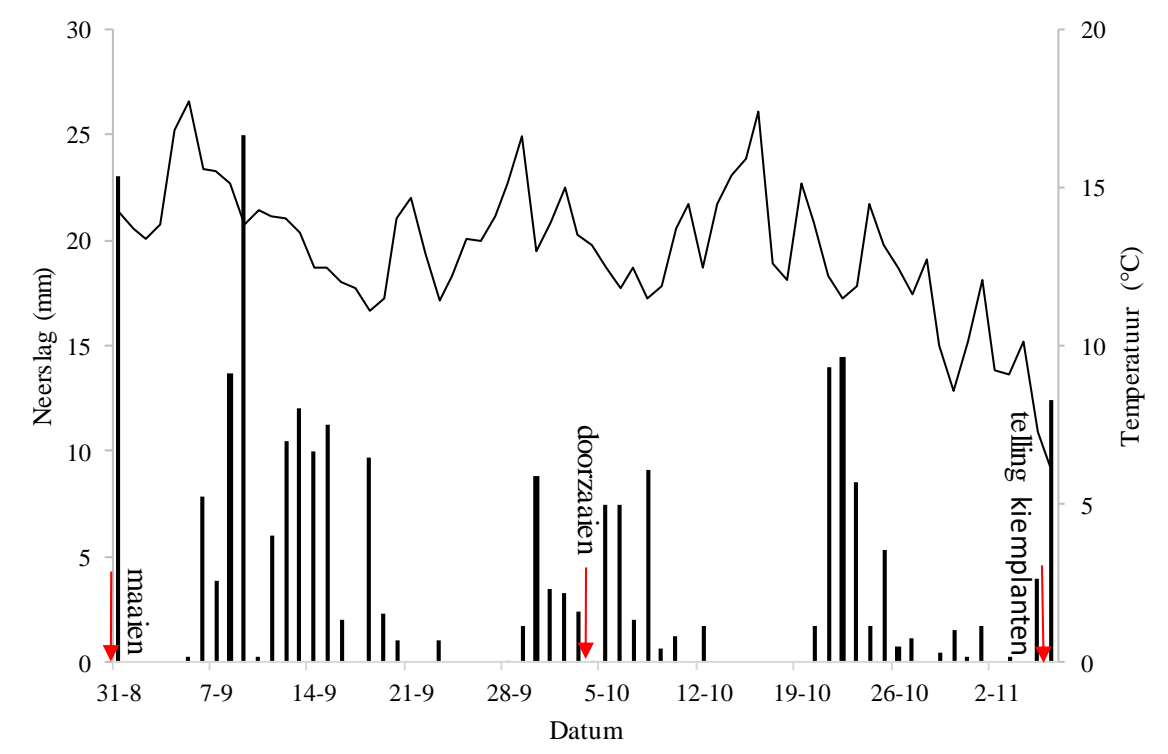

Figuur 2 Dagelijkse neerslag (kolommen, linker y-as) en gemiddelde temperatuur (lijn, rechter yas) in 2017 tussen het moment van maaien van de vierde snede en telling van de kiemplanten (gegevens KNMI-stations Skrins (neerslag) en Leeuwarden (temperatuur)).

\section{8}

In 2018 werd op 3 oktober doorgezaaid in een toplaag die zowel voldoende droog als voldoende vochtig was (Tabel 2). Hierdoor sneed de machine goed in de grond, werd het zaad goed verdeeld, en was er voldoende vocht beschikbaar voor een goede kieming. Vanwege de beperkte regenval na het doorzaaien werd er twee keer $10 \mathrm{~mm}$ water toegediend, 8 en 13 dagen na het doorzaaien (Fig. 3). De temperatuur was de eerste 14 dagen na het doorzaaien gemiddeld $14,9^{\circ} \mathrm{C}$.

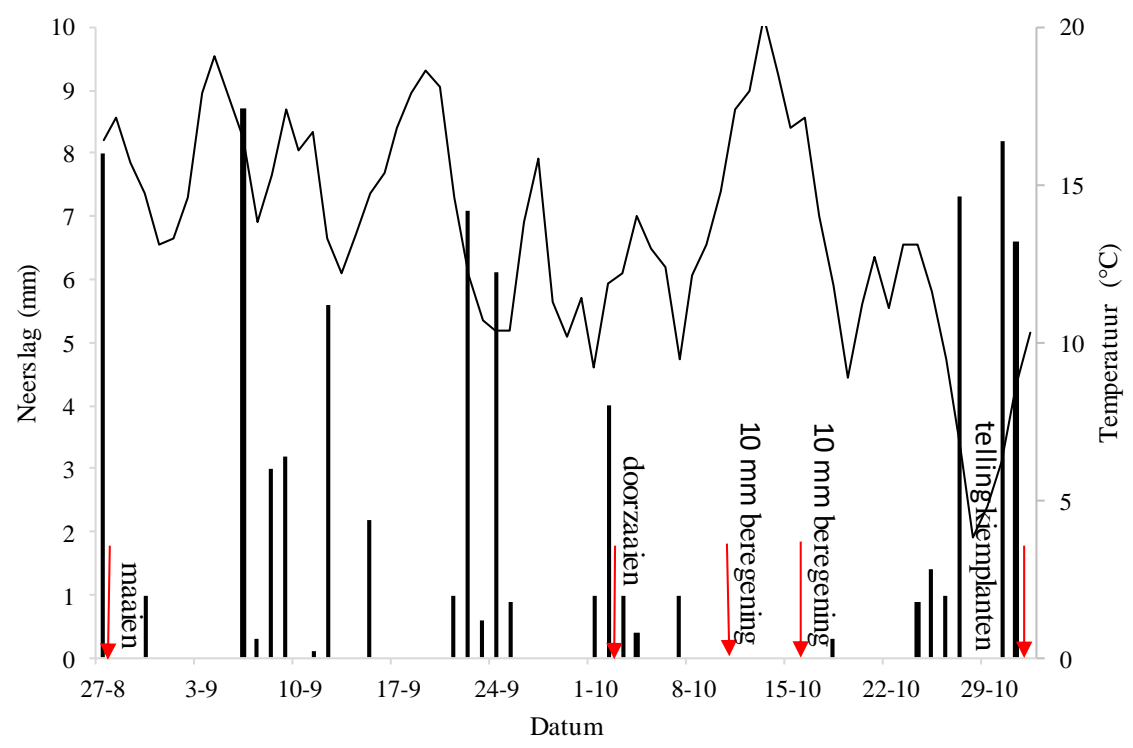

Figuur 3 Dagelijkse neerslag (kolommen, linker $y$-as) en gemiddelde temperatuur (lijn, rechter yas) in 2018 tussen het moment van maaien van de vierde snede en telling van de kiemplanten (gegevens KNMI-stations Skrins (neerslag) en Leeuwarden (temperatuur)).

\section{9}

In 2019 werd op 18 september doorgezaaid in een toplaag die zowel voldoende droog als voldoende vochtig was (Tabel 2 ). De machine sneed goed in de grond en het zaad werd goed verdeeld. Door het extra rollen van de doorgezaaide veldjes werden de zaaisneden volledig dichtgeduwd. Regenval was beperkt tijdens de kiemperiode maar regelmatig na start van de opkomst ( 25 september) (Fig. 4). 
Tien dagen na het doorzaaien waren er vier dagen met een relatief zware regenval van 13 tot $22 \mathrm{~mm}$ per dag. De temperatuur was de eerste 14 dagen na het doorzaaien gemiddeld $14,2{ }^{\circ} \mathrm{C}$.

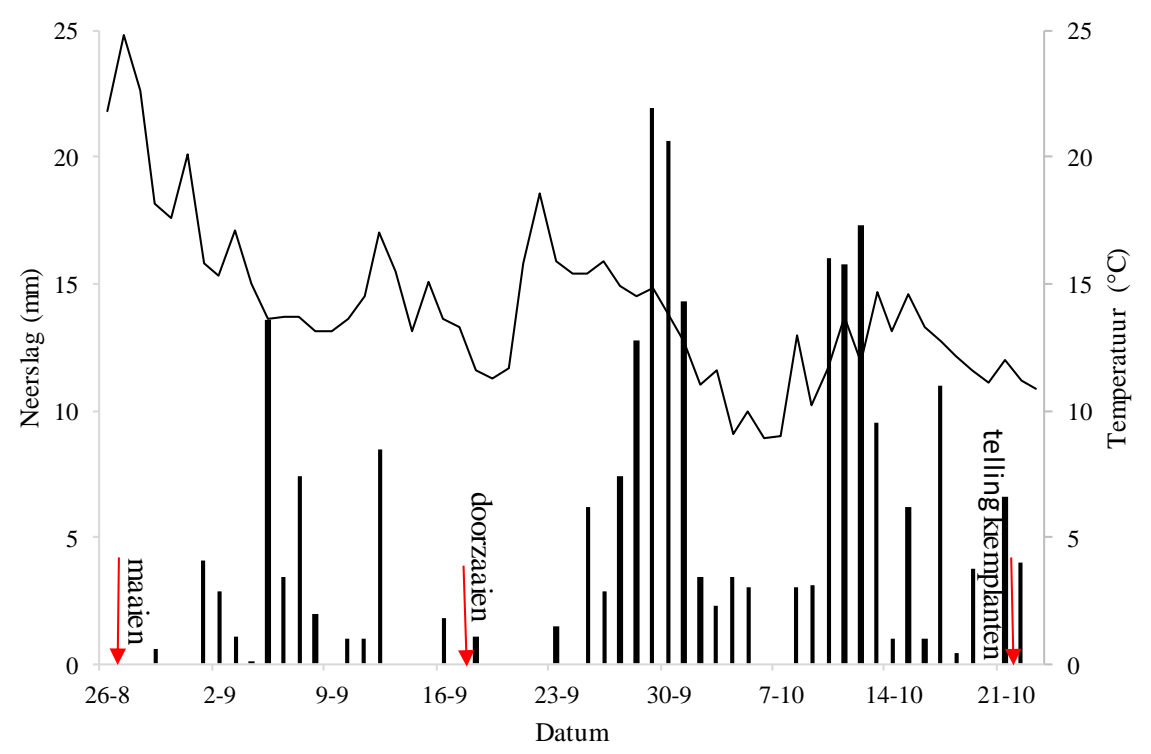

Figuur 4 Dagelijkse neerslag (kolommen, linker $y$-as) en gemiddelde temperatuur (lijn, rechter $y$ as) in 2019 tussen het moment van maaien van de vierde snede en telling van de kiemplanten (gegevens KNMI-stations Skrins (neerslag) en Leeuwarden (temperatuur)).

\subsection{Aantal kiemplanten}

Verschillen tussen jaren, behandelingen, en percelen Het aantal getelde kiemplanten was gemiddeld 28,30 , 84, en 418 planten per $\mathrm{m}^{2}$ in respectievelijk 2016, 2017, 2018, en 2019. In 2016 was er geen significant effect van perceel of behandeling op het aantal kiemplanten $(P>0,05)$. In 2017 was er, afhankelijk van perceel, een significant effect van behandeling $(P<0,01)$. Het aantal kiemplanten was op percelen 2 , 3, en 4 hoger bij behandeling 5 vergeleken met behandeling 6 , en was daarnaast op perceel 5 hoger dan op de andere percelen (Tabel 3). In 2018 was er eveneens een significant effect van behandeling, afhankelijk van perceel $(P<$ 0,05). Het aantal kiemplanten was op perceel 3 hoger bij behandeling 5 vergeleken met behandeling 6 (Tabel 3). Bij behandeling 5 was het aantal kiemplanten op perceel 1 significant hoger dan op percelen 2 en 3, en op perceel 5 significant hoger dan op perceel 2. Bij behandeling 6 was het aantal kiemplanten op percelen 1 en 5 significant hoger dan op percelen 2, 3, en 4.

Tabel 3 Aantal kiemplanten Engels raaigras (\# per $\mathrm{m}^{2}$ ) in 2018 en 2019 per perceel bij behandelingen 5 en 6, geteld vier tot zes weken na doorzaai van de graszode met Engels raaigras.

\begin{tabular}{llllllll} 
Jaar & Behandeling & Perceel & & & & & Gem. \\
& & 1 & 2 & 3 & 4 & 5 & \\
\hline 2017 & 5 & $29 \mathrm{a}^{1)}$ & $28 \mathrm{a}$ & $34 \mathrm{a}$ & $36 \mathrm{a}$ & $52 \mathrm{a}$ & \\
\hline 2018 & 6 & $22 \mathrm{a}$ & $16 \mathrm{~b}$ & $10 \mathrm{~b}$ & $11 \mathrm{~b}$ & $57 \mathrm{a}$ & 30 \\
\hline & 5 & $99 \mathrm{a}$ & $72 \mathrm{a}$ & $80 \mathrm{a}$ & $86 \mathrm{a}$ & $94 \mathrm{a}$ & \\
\hline
\end{tabular}

1) Een verschil in letters geeft een significant verschil aan binnen een combinatie van jaar en perceel $(P<0,05 ; L S D=12$ in 2017 en 19 in 2018$)$

In 2019 was er alleen een significant effect van perceel op het aantal kiemplanten $(P<0,001)$. Het aantal kiemplanten was op perceel 1 significant hoger dan op percelen $2 \mathrm{t} / \mathrm{m} 5$, en op percelen 3 en 5 significant hoger dan op perceel 4 (Tabel 4). 
Tabel 4 Aantal kiemplanten Engels raaigras (\# per $\mathrm{m}^{2}$ ) per perceel in 2019, gemiddeld over behandelingen 5 en 6, geteld vier tot zes weken na doorzaai van de graszode met Engels raaigras.

\begin{tabular}{llllll} 
Jaar & Perceel & 2 & 3 & 4 & 5 \\
\hline 2019 & 1 & $378 a b$ & $431 b$ & $345 a$ & $418 b$ \\
\hline
\end{tabular}

1) Een verschil in letters geeft een significant verschil aan $(P<0,001 ; L S D=53)$

\section{Tijdstip van tellen}

Bij de twee tellingen in 2019 was er alleen een significant effect van het tijdstip van tellen: het aantal gemiddelde kiemplanten was op 22 oktober (418 per $\mathrm{m}^{2}$ ) $4 \%$ hoger dan op 5 oktober (401 per $\left.\mathrm{m}^{2}\right)(\mathrm{P}$ $<0,001)$.

\section{Opkomst van het gezaaide zaad}

Tijdens de proefperiode werden er 868 tot 958 zaden per $\mathrm{m}^{2}$ gezaaid. De berekende opkomst was daarmee gemiddeld 3\%, 3\%, 10\%, en 46\% in respectievelijk 2016, 2017, 2018, en 2019.

Effect van behandeling op de bezetting door de graszode direct na doorzaaien In 2018 was er geen significant effect van tijdstip van meten op de totale bezetting (gem. 95\%; P > $0,05)$. In 2019 was er, afhankelijk van het perceel, een significant effect van het tijdstip van meten ( $P$ $<0,001)$. Op percelen 1,3 , en 4 was de totale bezetting direct na behandeling significant lager dan voorafgaande aan behandeling, met de grootste afname op perceel 4 (Tabel 5).

Tabel 5 Totale bezetting door de graszode (\%) voor en na behandeling in 2019, per perceel gemiddeld over behandelingen 5 en 6.

\begin{tabular}{|c|c|c|c|c|c|}
\hline \multirow[t]{2}{*}{ Tijdstip } & \multicolumn{5}{|l|}{ Perceel } \\
\hline & 1 & 2 & 3 & 4 & 5 \\
\hline Voor behandeling & $98,0 a^{1)}$ & $98,0 a$ & $98,0 a$ & $97,7 a$ & $98,0 a$ \\
\hline Na behandeling & $95,7 b$ & $96,2 a$ & $95,5 b$ & $86,5 b$ & $98,0 a$ \\
\hline
\end{tabular}

1) Een verschil in letters geeft een significant verschil aan binnen een perceel $(P<0,001 ; \operatorname{LSD}=2,2)$

In 2019, het jaar waarin behandeling leidde tot een significante afname van de totale bezetting, verklaarde de bezetting direct na behandeling $80 \%$ van de variantie in het aantal kiemplanten geteld op 22 oktober $(P<0,001)$. Op perceel 1 was er een significant negatieve relatie $(P<0,001)$ tussen bezetting (range 90-98\%) en aantal kiemplanten, en op perceel 4 (range $80-90 \%$ ) een aanwijzing voor een negatieve relatie ( $P=0,07$ ) (Fig. 5). Op deze percelen nam bij een 1 procentpunt (pp.) lagere bezetting het aantal kiemplanten toe met respectievelijk 20 en 8 planten per $\mathrm{m}^{2}$. 


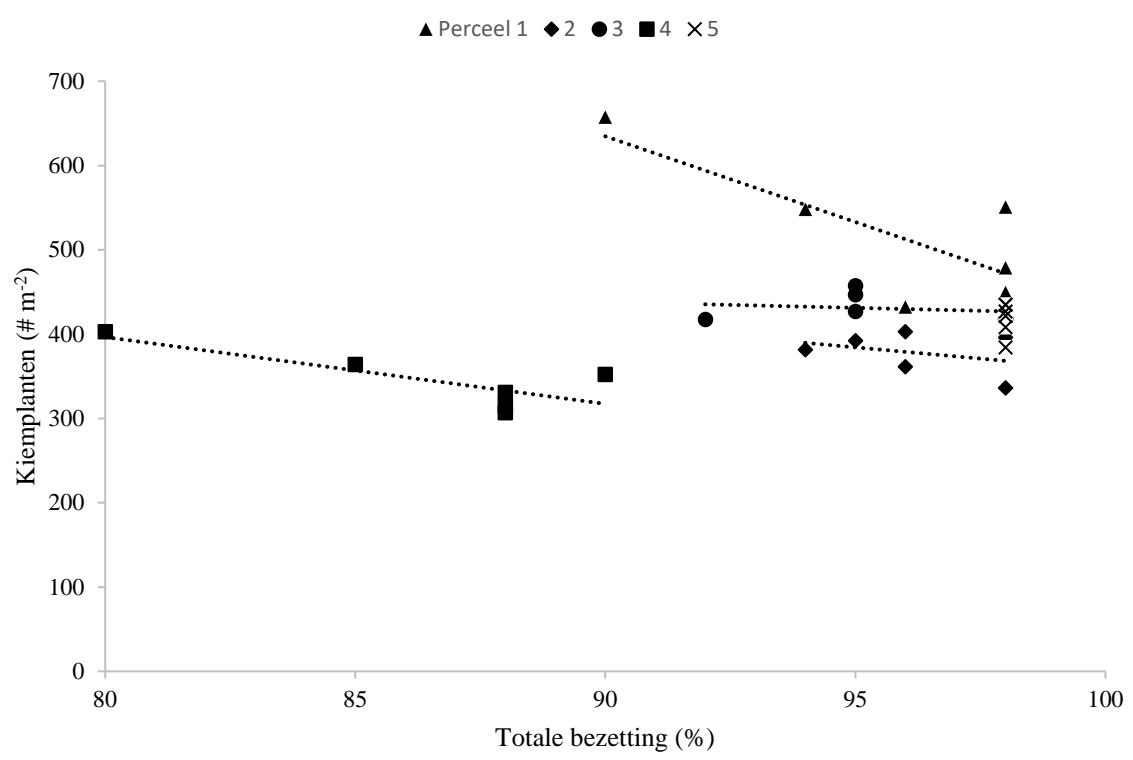

Figuur 5 Relaties tussen de totale bezetting door de graszode direct na behandeling en het aantal getelde kiemplanten in 2019, per perceel voor de data van behandelingen 5 en 6.

\subsection{Muizenschade}

Bij de scores voor muizenschade (voorjaar 2020) was er een significant effect van behandeling $(P<$ $0,001)$ en een aanwijzing voor een perceelafhankelijk effect van behandeling $(P=0,08)$. Bij het hoofdeffect van behandeling was de muizenschade bij behandelingen 5 en 6 significant lager dan bij behandelingen 1 t/m 4, en bij behandeling 2 significant lager dan bij behandeling 1 (Tabel 6). Bij de aanwijzing voor een perceelafhankelijk effect van behandeling was op perceel 1 de muizenschade bij behandeling 5 mogelijk lager dan bij behandelingen $1 \mathrm{t} / \mathrm{m} \mathrm{4}$, en bij behandeling 6 mogelijk lager dan bij behandelingen 2 en 3 (Tabel 6). Op perceel 2 was de muizenschade bij behandeling 6 mogelijk lager dan bij behandelingen $1 \mathrm{t} / \mathrm{m} \mathrm{4}$, bij behandeling 5 mogelijk lager dan bij behandelingen 1 , 3, en 4 , en bij behandeling 2 mogelijk lager dan bij behandelingen 1 en 3. Op perceel 3 was de muizenschade bij behandelingen 5 en 6 mogelijk lager dan bij behandelingen 1, 3, en 4, en bij behandeling 2 mogelijk lager dan bij behandelingen 1 en 3. Op perceel 4 was de muizenschade bij behandelingen 2, 5, en 6 mogelijk lager dan bij behandeling 4. Op perceel 5 was de muizenschade bij behandelingen 5 en 6 mogelijk lager dan bij behandelingen 1 t/m 4 .

Tabel 6 Muizenschade op 6 maart 2020, gescoord op een schaal van 1 t/m 9 (1 = veel schade, 9 = weinig schade), per perceel per behandeling.

\begin{tabular}{lllllll} 
Behandeling & Perceel & & & & Gem. \\
& 1 & 2 & 3 & 4 & 5 & \\
\hline 1 & $5,3 a b^{1)}$ & $3,3 a$ & $2,7 a$ & $5,3 a b$ & $4,7 a$ & $4,3 a b$ \\
\hline 2 & $4,7 a$ & $5,3 b c$ & $5,3 b c$ & $6,0 b$ & $3,7 a$ & $5,0 b$ \\
\hline 3 & $4,7 a$ & $3,3 a$ & $3,3 a$ & $5,0 a b$ & $3,7 a$ & $4,0 a$ \\
\hline 5 & $5,3 a b$ & $3,7 a b$ & $4,3 a b$ & $3,7 a$ & $4,3 a$ & $4,3 a b$ \\
\hline 6 & $7,3 c$ & $6,7 c d$ & $6,3 c$ & $6,7 b$ & $7,0 b$ & $6,8 c$ \\
\hline Gem. & $6,7 b c$ & $7,7 d$ & $6,3 c$ & $6,0 b$ & $7,0 b$ & $6,7 c$ \\
\hline
\end{tabular}

1) Een verschil in letters geeft een significant verschil aan tussen gemiddelden van percelen of een aanwijzing voor een significant verschil tussen behandelingen binnen een perceel $(P<0,001$ of $P=0,08$; $L S D=0,8$ of $1,7 \mathrm{pp}$.) 


\subsection{Botanische samenstelling}

Tijdstip van karteren

In 2017 en 2018 was er, afhankelijk van perceel, een significant effect van tijdstip van karteren ( $P<$ 0,001) (Tabel 7). In 2017 was het aandeel Engels raaigras op percelen 1, 3, en 4 in de zomer significant hoger dan in het voorjaar, op perceel 2 significant lager dan in het voorjaar, en op perceel 5 was er geen significant verschil. In 2018 was het aandeel Engels raaigras op percelen 2, 3, en 4 in de zomer significant hoger dan in het voorjaar, en op percelen 1 en 5 significant lager dan in het voorjaar $(P<0,001)$.

Tabel 7 Aandeel Engels raaigras (\%) in de graszode bij voorjaars-en zomerkartering in 2018 en 2019, per perceel gemiddeld over de behandelingen.

\begin{tabular}{lllllll} 
Jaar & Tijistip karteren & Perceel & & & \\
& & 1 & 2 & 3 & 4 & 5 \\
\hline \multirow{2}{*}{2017} & Voorjaar & $48,1 \mathrm{a}^{1)}$ & $74,7 \mathrm{a}$ & $68,7 \mathrm{a}$ & $35,3 \mathrm{a}$ & $79,8 \mathrm{a}$ \\
\hline \multirow{2}{*}{2018} & Zomer & $53,6 \mathrm{~b}$ & $71,6 \mathrm{~b}$ & $72,2 \mathrm{~b}$ & $37,1 \mathrm{~b}$ & $80,6 \mathrm{a}$ \\
\hline & Voorjaar & $52,8 \mathrm{a}$ & $71,6 \mathrm{a}$ & $72,2 \mathrm{a}$ & $36,8 \mathrm{a}$ & $77,0 \mathrm{a}$ \\
\hline
\end{tabular}

1) Een verschil in letters geeft een significant verschil aan binnen combinaties van jaar en perceel $(P<0,001 ;$ LSD = 1,2 in 2017 en 1,0 in 2018$)$

In 2019 was er, afhankelijk van behandeling, een significant effect van tijdstip van karteren op het aandeel Engels raaigras $(P<0,001)$. Bij behandelingen 5 en 6 was het aandeel in de zomer significant hoger dan in het voorjaar (Tabel 8).

Tabel 8 Aandeel Engels raaigras (\%) in de graszode bij voorjaars- en zomerkartering in 2019, per behandeling gemiddeld over de percelen.

\begin{tabular}{|c|c|c|c|c|c|c|c|}
\hline \multirow[t]{2}{*}{ Jaar } & \multirow[t]{2}{*}{ Tijdstip karteren } & \multicolumn{6}{|c|}{ Behandeling } \\
\hline & & 1 & 2 & 3 & 4 & 5 & 6 \\
\hline \multirow[t]{2}{*}{2019} & Voorjaar & $62,5 a^{1)}$ & $62,5 a$ & $62,6 a$ & $62,5 a$ & $65,3 a$ & $66,1 \mathrm{a}$ \\
\hline & Zomer & $62,7 a$ & $62,5 a$ & $62,9 a$ & $62,7 a$ & $67,7 b$ & $68,0 \mathrm{~b}$ \\
\hline
\end{tabular}

1) Een verschil in letters geeft een significant verschil aan binnen een behandeling $(P<0,001 ; \operatorname{LSD}=0,7)$

In 2020 was er, afhankelijk van perceel en behandeling, een aanwijzing voor een effect van tijdstip van karteren op het aandeel Engels raaigras $(P=0,05)$. Op percelen 1 en 4 was, evenals in het voorgaande jaar, het aandeel Engels raaigras bij behandelingen 5 en 6 in de zomer mogelijk significant hoger dan in het voorjaar (Tabel 9).

Tabel 9 Aandeel Engels raaigras (\%) in de graszode bij voorjaars- en zomerkartering in 2020, per perceel per behandeling.

\begin{tabular}{|c|c|c|c|c|c|c|c|}
\hline \multirow[t]{2}{*}{ Perceel } & \multirow[t]{2}{*}{ Tijdstip karteren } & \multicolumn{6}{|c|}{ Behandeling } \\
\hline & & 1 & 2 & 3 & 4 & 5 & 6 \\
\hline \multirow[t]{2}{*}{1} & Voorjaar & $46,3 a^{1)}$ & $46,0 a$ & $48,0 \mathrm{a}$ & $45,3 a$ & $46,3 a$ & $48,0 a$ \\
\hline & Zomer & $47,0 a$ & $45,7 a$ & $48,0 a$ & $45,3 a$ & $49,3 b$ & $51,3 b$ \\
\hline \multirow[t]{2}{*}{2} & Voorjaar & $55,0 a$ & $63,7 a$ & $61,7 a$ & $59,0 a$ & $68,3 a$ & $71,0 a$ \\
\hline & Zomer & $53,7 b$ & $64,0 a$ & $59,0 \mathrm{~b}$ & $57,3 b$ & $68,0 a$ & $70,3 a$ \\
\hline \multirow[t]{2}{*}{3} & Voorjaar & $65,3 a$ & $66,0 a$ & $66,0 \mathrm{a}$ & $66,7 a$ & $71,0 \mathrm{a}$ & $72,7 a$ \\
\hline & Zomer & $63,0 b$ & $65,0 \mathrm{a}$ & $64,0 \mathrm{~b}$ & $65,3 b$ & $70,0 \mathrm{a}$ & $72,0 a$ \\
\hline \multirow[t]{2}{*}{4} & Voorjaar & $31,7 a$ & $31,7 a$ & $29,7 a$ & $32,7 a$ & $35,0 a$ & $34,7 a$ \\
\hline & Zomer & $32,0 a$ & $31,7 a$ & $29,3 a$ & $31,7 a$ & $36,3 b$ & $36,3 b$ \\
\hline \multirow[t]{2}{*}{5} & Voorjaar & $69,0 a$ & $68,0 a$ & $70,0 a$ & $69,0 a$ & $69,3 a$ & $67,7 a$ \\
\hline & Zomer & $69,7 a$ & $68,7 a$ & $70,0 a$ & $69,0 a$ & $70,0 a$ & $67,7 a$ \\
\hline
\end{tabular}

1) Een verschil in letters geeft een aanwijzing voor een significant verschil binnen een combinatie van perceel en behandeling $(P=0,05 ;$ LSD =

$1,2)$ 
Op percelen 2 en 3 was het aandeel Engels raaigras bij behandelingen 1, 3, en 4 in de zomer mogelijk lager dan in het voorjaar, en op perceel 5 was er geen verschil. Omdat effecten van behandeling op het aandeel Engels raaigras in de zomer meestal verder tot uitdrukking waren gekomen dan in het voorjaar, zijn bij verdere analyse de gegevens van de zomerkartering gebruikt.

\section{Bezetting door de graszode}

In de zomer van 2016 en 2017 waren er geen significante effecten van perceel of behandeling op de bezetting door de graszode (gem. 97,6\% en 97,6\%) ( $P>0,05$ ). In de zomer van 2018 was er een significant effect van perceel, met een significant lagere bezetting op perceel 1 vergeleken met percelen $2 \mathrm{t} / \mathrm{m} 5(\mathrm{P}<0,001)$ (Tabel 10).

Tabel 10 Bezetting door de graszode (\%) in de zomer van 2018, per perceel gemiddeld over de behandelingen.

\begin{tabular}{|c|c|c|c|c|c|}
\hline Jaar & \multicolumn{5}{|c|}{ Perceel } \\
\hline 2018 & $89,7 a$ & $98,0 b$ & $98,0 b$ & $96,0 b$ & $98,0 b$ \\
\hline
\end{tabular}

1) Een verschil in letters geeft een significant verschil aan $(P<0,001 ; \operatorname{LSD}=2,6)$

In de zomer van 2019 was er, afhankelijk van perceel, een significant effect van behandeling op de bezetting door de graszode $(P<0,001)$. Op perceel 3 was de bezetting bij behandeling 1 significant lager dan bij de andere behandelingen (Tabel 11). Op perceel 4 was de bezetting bij behandeling 6 significant hoger dan bij behandelingen $1 \mathrm{t} / \mathrm{m} \mathrm{5}$, en bij behandelingen 2 en 5 significant hoger dan bij behandelingen 1 , 3, en 4 .

Tabel 11 Bezetting door de graszode (\%) in de zomer van 2019, per perceel per behandeling.

\begin{tabular}{llllll} 
Behandeling & Perceel & 2 & 3 & 4 & 5 \\
\hline 1 & 1 & $98,0 \mathrm{a}$ & $97,3 \mathrm{a}$ & $95,7 \mathrm{a}$ & $98,0 \mathrm{a}$ \\
\hline 2 & $98,0 \mathrm{a}^{1)}$ & $98,0 \mathrm{a}$ & $98,0 \mathrm{~b}$ & $97,3 \mathrm{~b}$ & $98,0 \mathrm{a}$ \\
\hline 3 & $98,0 \mathrm{a}$ & $98,0 \mathrm{a}$ & $98,0 \mathrm{~b}$ & $96,0 \mathrm{a}$ & $98,0 \mathrm{a}$ \\
\hline 4 & $98,0 \mathrm{a}$ & $98,0 \mathrm{a}$ & $98,0 \mathrm{~b}$ & $96,0 \mathrm{a}$ & $9 \mathrm{a}$ \\
\hline 6 & $98,0 \mathrm{a}$ & $98,0 \mathrm{a}$ & $98,0 \mathrm{~b}$ & $97,3 \mathrm{~b}$ & $98,0 \mathrm{a}$ \\
\hline
\end{tabular}

1) Een verschil in letters geeft een significant verschil aan binnen een perceel $(P<0,001 ; L S D=0,6)$

In de zomer van 2020 was er een significant effect van perceel op de bezetting door de graszode $(P<$ $0,001)$. De bezetting was op percelen 2 en 3 significant hoger dan op percelen 4 en 5 , en op percelen 1 en 5 significant hoger dan op perceel 4 (Tabel 12). In het voorjaar van 2021 was er geen significant effect van perceel of behandeling op de bezetting op percelen 2 en 3 (gemiddeld 98,0\%) $(P>0,05)$.

Tabel 12 Bezetting door de graszode (\%) in de zomer van 2020, per perceel gemiddeld over de behandelingen.

\begin{tabular}{llllll} 
Jaar & Perceel & & & & 4 \\
\\
\hline 2020 & 1 & 2 & 3 & $95,4 a$ & 5 \\
\hline
\end{tabular}

1) Een verschil in letters geeft een significant verschil aan $(P<0,001 ; L S D=0,5)$

\section{Aandeel Engels raaigras - vergelijking binnen jaren}

In alle jaren verschilden de percelen significant in het aandeel Engels raaigras in de zomer $(\mathrm{P}<$ 0,001). In 2016, bij start van het onderzoek, was het aandeel Engels raaigras het hoogst op perceel 5 , gevolgd door percelen 2, 3, 1, en tenslotte perceel 4 (Fig. 6). In 2017 was de volgorde hetzelfde, behalve dat er geen significant verschil was tussen percelen 2 en 3 . In 2018 was het aandeel Engels raaigras het hoogst op percelen 2, 3, en 5, gevolgd door perceel 1, en tenslotte perceel 4. In 2019 was het aandeel Engels raaigras weer het hoogst op perceel 5, gevolgd door percelen 2 en 3, daarna 
perceel 1, en tenslotte perceel 4. In 2020 was het aandeel Engels raaigras nog steeds het hoogst op perceel 5, gevolgd door perceel 3, perceel 2, perceel 1, en perceel 4.

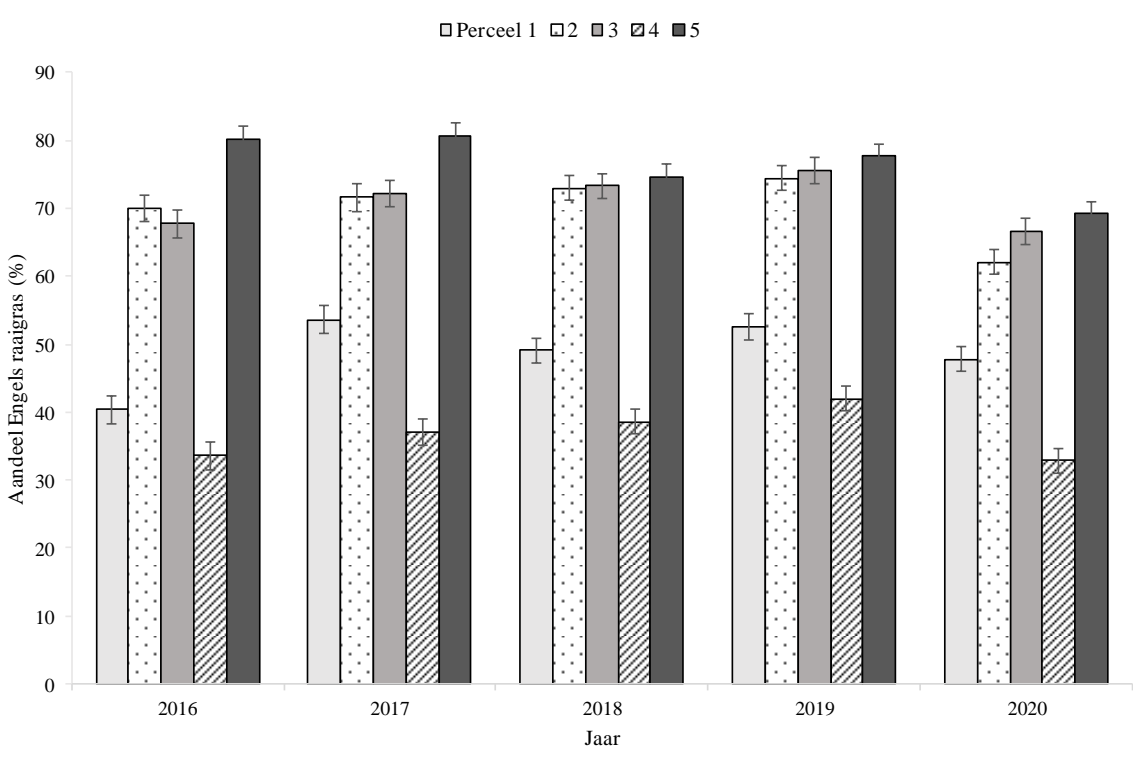

Figuur 6 Aandeel Engels raaigras (\%) in de zomer van 2016 t/m 2020, per perceel gemiddeld over de behandelingen. Foutenbalken vertegenwoordigen de $L S D$ binnen jaren $(P<0,001)$.

In de zomers van 2016, 2017, en 2018 waren er geen significante effecten van behandeling op het aandeel Engels raaigras $(P>0,05)$. In de zomer van 2019 was er, naast het effect van perceel, ook een significant effect van behandeling op het aandeel Engels raaigras $(P<0,001)$. Het aandeel Engels raaigras was bij behandelingen 5 en 6 significant hoger dan bij behandelingen $1 \mathrm{t} / \mathrm{m} 4$ (Tabel 13). De toename was, gemiddeld over de percelen en behandelingen, 5,1 pp. bij behandelingen 5 en 6 vergeleken met behandelingen $1 \mathrm{t} / \mathrm{m} 4$. Opgesplitst per perceel was deze gemiddelde toename 6,9, $6,3,5,7,5,3$, en $1,5 \mathrm{pp}$. voor respectievelijk percelen $1 \mathrm{t} / \mathrm{m} 5$.

Tabel 13 Aandeel Engels raaigras (\%) in de graszode in de zomer van 2019, per behandeling gemiddeld over de percelen.

\begin{tabular}{|c|c|c|c|c|c|c|}
\hline Jaar & \multicolumn{6}{|c|}{ Behandeling } \\
\hline 2019 & $62,7 b^{1)}$ & $62,5 b$ & $62,9 b$ & $62,7 b$ & $67,7 a$ & $68,0 a$ \\
\hline
\end{tabular}

1) Een verschil in letters geeft een significant verschil aan $(P<0,001 ; \operatorname{LSD}=2,0)$

In de zomer van 2020 was er, afhankelijk van perceel, een significant effect van behandeling op het aandeel Engels raaigras $(P<0,001)$. Op perceel 1 was het aandeel Engels raaigras bij behandeling 6 significant hoger dan bij behandelingen 2 en 4 (Fig. 7). Op perceel 2 was het aandeel Engels raaigras bij behandeling 6 significant hoger dan bij behandelingen 1 t/m 4, bij behandelingen 2 en 5 significant hoger dan bij behandelingen 1, 3, en 4, en bij behandeling 3 significant hoger dan bij behandeling 1. Op perceel 3 was het aandeel Engels raaigras bij behandelingen 5 en 6 significant hoger dan bij behandelingen $1 \mathrm{t} / \mathrm{m} 4$. Op perceel 4 was het aandeel Engels raaigras bij behandelingen 5 en 6 significant hoger dan bij behandelingen $2 \mathrm{t} / \mathrm{m} 4$. Op perceel 5 waren er geen significante verschillen tussen behandelingen. 


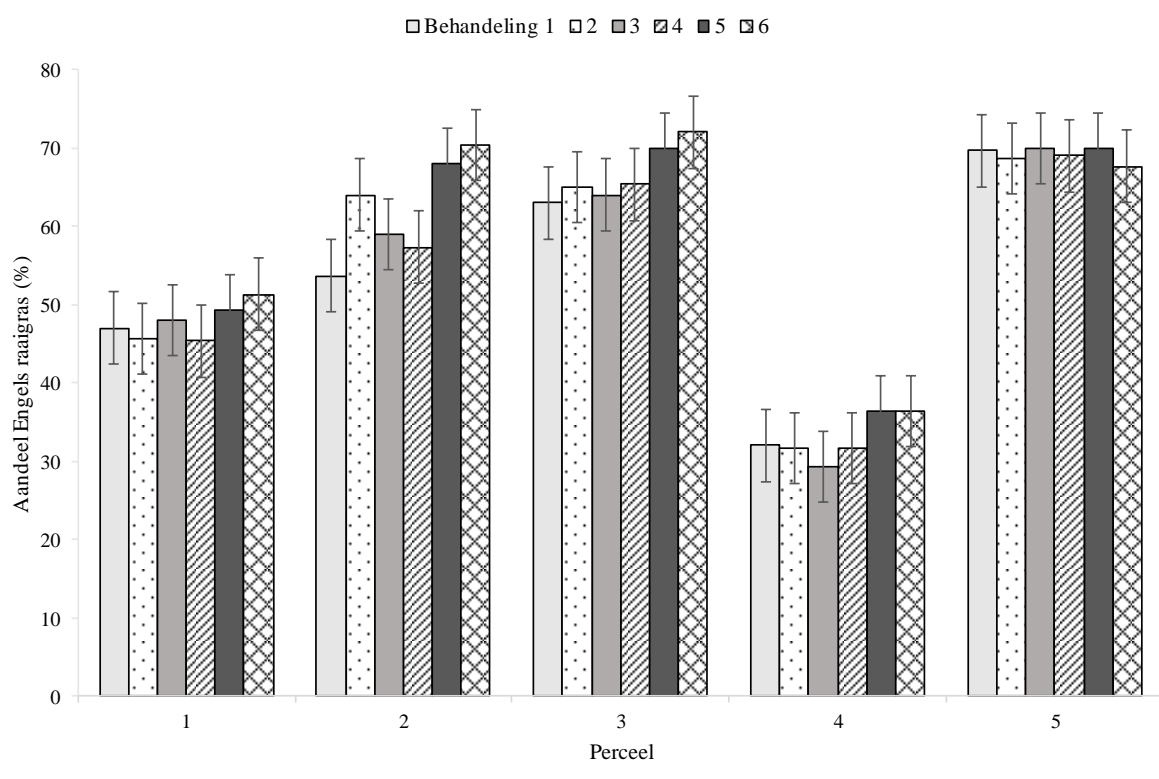

Figuur 7 Aandeel Engels raaigras (\%) in de zomer van 2020, per perceel per behandeling. Foutenbalken vertegenwoordigen de LSD binnen percelen $(P<0,001)$.

In het voorjaar van 2021 was er een significant effect van perceel en een significant effect van behandeling op het aandeel Engels raaigras $(P<0,01$ en $P<0,001)$. Het aandeel Engels raaigras was significant hoger op perceel 3 (gem. 67\%) vergeleken met perceel 2 (gem. 63\%). Bij behandelingen 5 en 6 was het aandeel Engels raaigras significant hoger dan bij behandelingen $1 \mathrm{t} / \mathrm{m} \mathrm{4}$, en bij behandeling 2 significant hoger dan bij behandelingen 1 en 4 (Tabel 14).

Tabel 14 Aandeel Engels raaigras (\%) in de graszode van percelen 2 en 3 in het voorjaar van 2021, per behandeling gemiddeld over de percelen.

\begin{tabular}{lllllll} 
& Behandeling & & & & \\
& 1 & 2 & 3 & 4 & 5 & 6 \\
\hline 2021 & $59,5 \mathrm{a}^{1)}$ & $64,8 \mathrm{~b}$ & $61,5 \mathrm{ab}$ & $60,8 \mathrm{a}$ & $71,2 \mathrm{c}$ & $73,2 \mathrm{c}$ \\
\hline
\end{tabular}

1) Een verschil in letters geeft een significant verschil aan $(P<0,001 ; L S D=3,9)$

Aandeel Engels raaigras - verandering in de tijd

Tussen de zomer van 2016 en de zomer van 2019 (de laatste kartering voorafgaande aan de zware muizenschade) waren er op de onbehandelde veldjes (behandeling 1), afhankelijk van perceel, significante verschillen in aandeel Engels raaigras $(P<0,01)$. Op percelen 1,3 , en 4 was het aandeel significant hoger, met respectievelijk gemiddeld 11,3, 7,0, en 7,7 pp. (Tabel 15). Op percelen 2 en 5 was het aandeel onveranderd, met aandelen van respectievelijk gemiddeld $69,8 \%$ en $78,5 \%$.

Op perceel 1 ging de toename van aandeel Engels raaigras van $11 \%$ samen met een afname in aandeel ruw beemdgras van 15\%, op perceel 3 ging de toename van Engels raaigras met $7 \%$ samen met een afname in aandeel ruw beemdgras van $6 \%$, en op perceel 4 ging de toename van aandeel Engels raaigras van $8 \%$ samen met een toename van aandeel ruw beemdgras van $9 \%$ (Tabel 15). Op perceel 4 nam het aandeel paardenbloem significant af, van 34\% tot $0 \%$ (als gevolg van chemische bestrijding in het voorjaar van 2017), nam het aandeel kweekgras (Elymus repens L.) significant toe van $5 \%$ tot $11 \%$, en nam het aandeel zachte dravik (Bromus hordeaceus L.) significant toe van 0 tot $12 \%$. Op perceel 2 bleef het aandeel straatgras (Poa annua L.) stabiel op 9\%, en op perceel 5 nam het aandeel timotheegras (Phleum pratense L. subsp. pratense) af van $20 \%$ tot $17 \%$. 
Tabel 15 Veranderingen in aandeel van Engels raaigras (\%) en andere meest aanwezige soorten in de graszode van de controleveldjes, tussen de zomer van 2016 en 2019, per perceel.

\begin{tabular}{|c|c|c|c|c|c|c|c|c|}
\hline Perceel & Tijdstip & $\begin{array}{l}\text { Engels } \\
\text { raaigras }\end{array}$ & $\begin{array}{l}\text { Ruw } \\
\text { beemdgras }\end{array}$ & Straatgras & Kweekgras & Timothee & $\begin{array}{l}\text { Zachte } \\
\text { dravik }\end{array}$ & Paardenbloem \\
\hline \multirow[t]{2}{*}{1} & 2016 & $38 a^{1)}$ & $62 a$ & 0a & $0 a$ & $0 a$ & $0 a$ & $0 a$ \\
\hline & 2019 & $50 b$ & $47 b$ & $0 \mathrm{a}$ & $0 a$ & $0 a$ & $0 a$ & $2 a$ \\
\hline 2 & 2016 & $68 a$ & $22 a$ & $9 a$ & $0 a$ & $0 a$ & $0 a$ & $0 a$ \\
\hline 3 & 2019 & $74 b$ & $25 b$ & $0 a$ & $1 a$ & $0 a$ & $0 a$ & 0a \\
\hline \multirow[t]{2}{*}{4} & 2016 & $33 a$ & $27 a$ & $0 \mathrm{a}$ & $5 a$ & $0 a$ & $0 \mathrm{a}$ & $35 a^{2)}$ \\
\hline & 2019 & $41 \mathrm{~b}$ & $36 \mathrm{~b}$ & $0 a$ & $11 \mathrm{~b}$ & $0 a$ & $12 b$ & ob \\
\hline 5 & 2016 & $79 a$ & $0 a$ & $0 a$ & $0 a$ & $20 a$ & $0 a$ & $0 a$ \\
\hline
\end{tabular}

1) Een verschil in letters geeft een significant verschil aan binnen perceel en soort $(P<0,05)$

2) In het voorjaar van 2017 was paardenbloem volledig verdwenen als gevolg van chemische bestrijding

Ook tussen de zomer van 2016 en de zomer van 2020 waren er op de onbehandelde veldjes, afhankelijk van perceel, significante veranderingen van het aandeel Engels raaigras $(P<0,001$; Tabel 16). Perceel 1 was het enige perceel met een significante toename van het aandeel Engels raaigras, met gemiddeld $9 \mathrm{pp}$. Op percelen 2 en 5 was er een significante afname in aandeel, met respectievelijk gemiddeld 15 en 10 pp., en op percelen 3 en 4 veranderden de aandelen niet significant. Deze veranderingen laten zien dat muizenschade een aanzienlijk negatief effect kan hebben op de ontwikkeling van het aandeel Engels raaigras over de tijd.

Tabel 16 Verandering in aandeel (\%) Engels raaigras in de graszode van de controleveldjes tussen de zomer van 2016 en de zomer van 2020, per perceel.

\begin{tabular}{|c|c|c|c|c|c|}
\hline \multirow[t]{2}{*}{ Tijdstip } & \multicolumn{5}{|c|}{ Perceel } \\
\hline & 1 & 2 & 3 & 4 & 5 \\
\hline Augustus 2016 & $38,3 a$ & $68,3 a$ & $67,3 a$ & $33,0 a$ & $79,3 a$ \\
\hline Augustus 2020 & $47,0 b$ & $53,7 b$ & $63,0 a$ & $32,0 a$ & $69,7 b$ \\
\hline
\end{tabular}

1) Een verschil in letters geeft een significant verschil aan binnen een perceel $(P<0,001$; LSD $=5,4)$

De afname in aandeel Engels raaigras tussen de zomer van 2019 en het voorjaar van 2020 ging samen met een aanzienlijke significante toename van aandeel ruw beemdgras (percelen $2 \mathrm{t} / \mathrm{m} 5$ ) en een kleinere significante toename van straatgras (perceel 2) (Tabel 17).

Tabel 17 Veranderingen in aandeel van Engels raaigras (\%) en andere meest aanwezige soorten in de graszode van de controleveldjes, tussen de zomer van 2019 en het voorjaar van 2020, per perceel.

\begin{tabular}{|c|c|c|c|c|c|c|c|c|}
\hline Perceel & Tijdstip & $\begin{array}{l}\text { Engels } \\
\text { raaigras }\end{array}$ & $\begin{array}{l}\text { Ruw } \\
\text { beemdgras }\end{array}$ & Straatgras & Kweekgras & Timothee & $\begin{array}{l}\text { Zachte } \\
\text { dravik }\end{array}$ & Paardenbloem \\
\hline \multirow[t]{2}{*}{1} & 2019 & $50 a$ & $47 a$ & $0 a$ & $0 a$ & $0 a$ & $0 a$ & $2 a$ \\
\hline & 2020 & $46 a$ & $48 a$ & $2 a$ & $1 a$ & $0 a$ & $1 \mathrm{a}$ & $\mathrm{Ob}$ \\
\hline 2 & 2019 & $71 a$ & $17 a$ & $9 a$ & $1 a$ & 0a & $0 a$ & $0 a$ \\
\hline 3 & 2020 & $65 b$ & $32 b$ & $2 a$ & $1 a$ & $0 a$ & $0 a$ & $0 a$ \\
\hline \multirow[t]{2}{*}{4} & 2019 & $41 a$ & $36 a$ & $0 a$ & $11 a$ & $0 \mathrm{a}$ & $12 a$ & $0 \mathrm{a}$ \\
\hline & 2020 & $32 b$ & $43 b$ & $0 a$ & $11 a$ & $0 a$ & $13 a$ & $0 a$ \\
\hline 5 & 2019 & $78 a$ & $5 a$ & $0 a$ & $0 a$ & $17 a$ & $0 a$ & $0 a$ \\
\hline
\end{tabular}

1) Een verschil in letters geeft een significant verschil aan tussen tijdstip van karteren binnen perceel en soort $(P<0,05)$ 
Op perceel 1 werden in de proefperiode de hoogste aandelen Engels raaigras gerealiseerd in de zomer van 2019 (Fig. 8), met ook de grootste verschillen tussen behandelingen 1 en 2 en behandelingen 5 en 6 . In het voorjaar van 2020, na de zware muizenvraat, was een groot deel van deze verschillen verdwenen, en in de zomer van 2020 was dit nog steeds het geval.

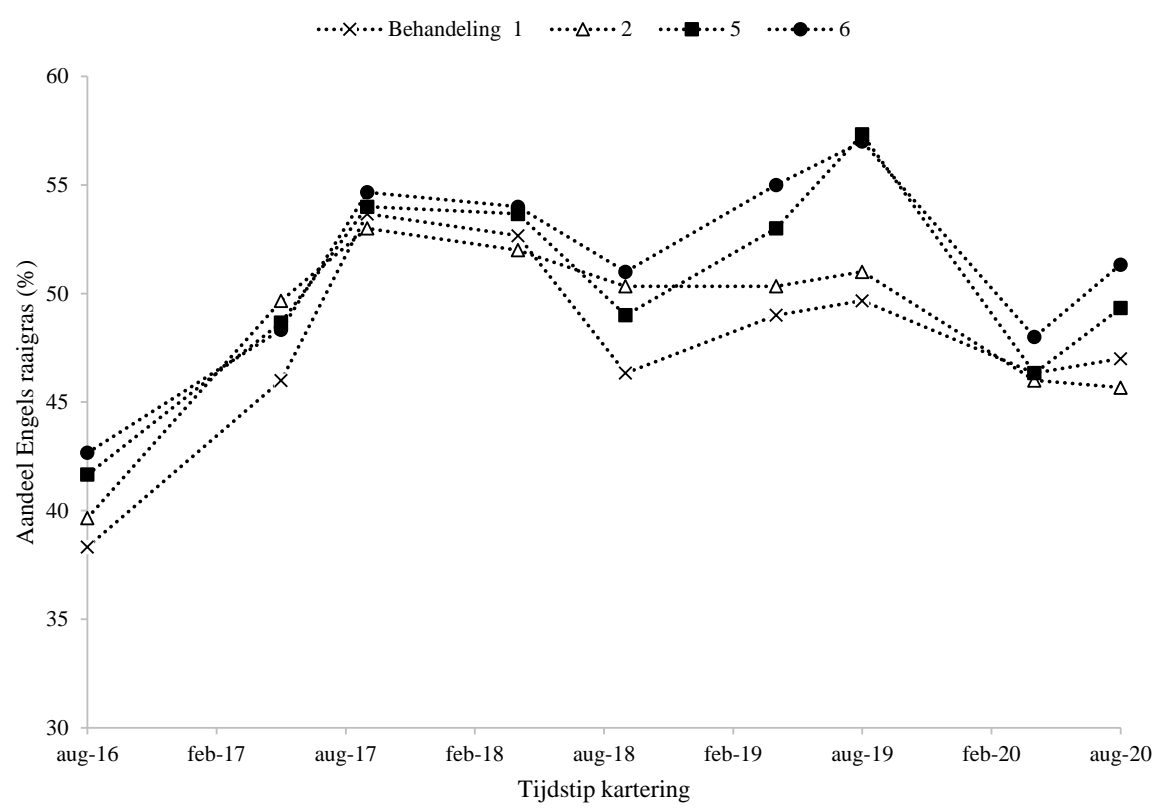

Figuur 8 Verandering in aandeel Engels raaigras (\%) over de proefperiode op perceel 1 bij behandelingen $1,2,5$, en 6 .

Op perceel 2 waren verschillen tussen behandelingen na de zomer van 2019 vooral het gevolg van een kleinere afname in aandeel Engels raaigras bij behandelingen 2, 5, en 6, dan bij behandeling 1 (Fig. $9)$.

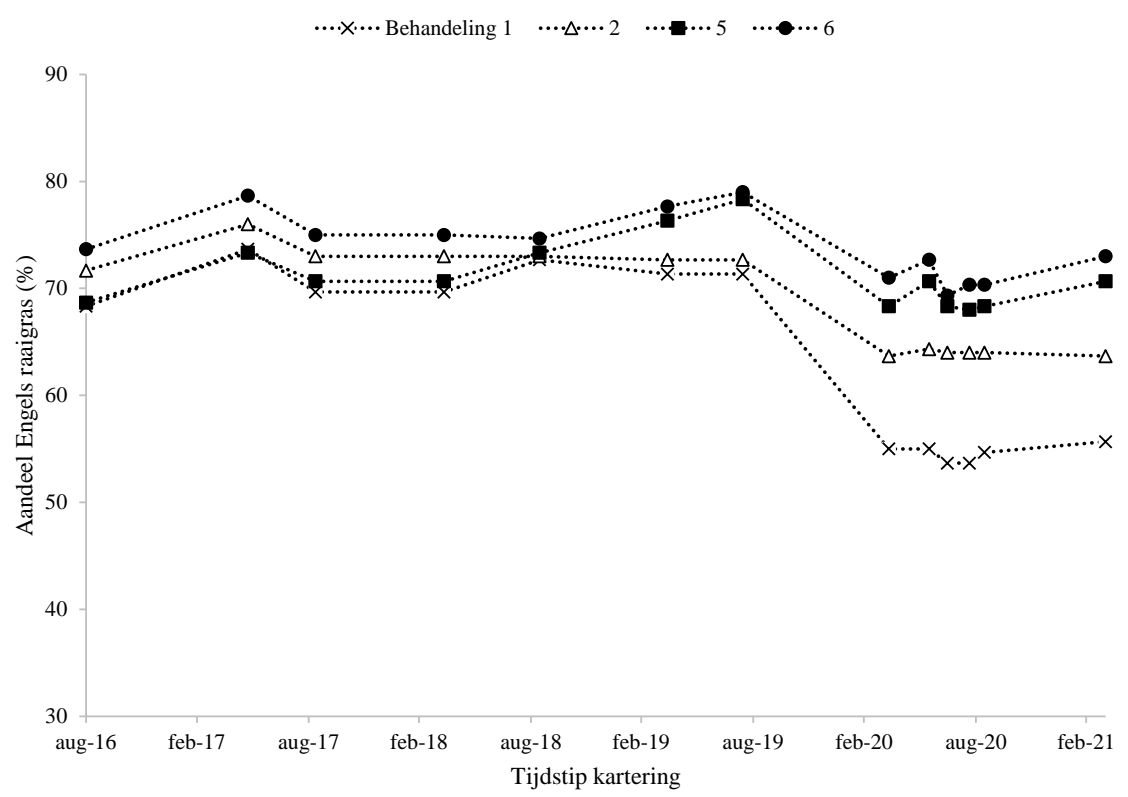

Figuur 9 Verandering in aandeel Engels raaigras (\%) over de proefperiode op perceel 2 bij behandelingen $1,2,5$, en 6 . 
Op perceel 3 was het beeld grotendeels vergelijkbaar met perceel 2, met kleinere verschillen tussen behandelingen $2,5,6$, en behandeling 1 , en een kleiner verschil tussen behandeling 2 en behandeling 1 (Fig. 10).

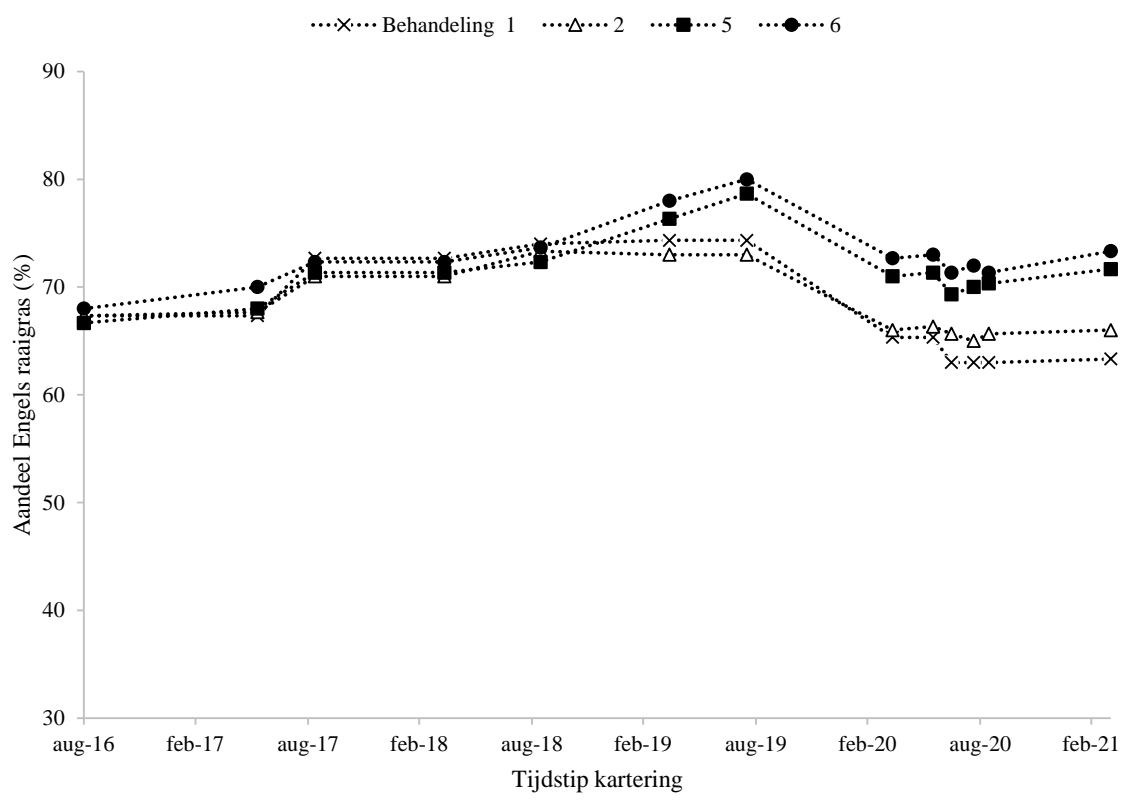

Figuur 10 Verandering in aandeel Engels raaigras (\%) over de proefperiode op perceel 3 bij behandelingen 1, 2, 5, en 6 .

Op perceel 4 was er, evenals bij percelen $1 \mathrm{t} / \mathrm{m} \mathrm{3}$, sprake van een terugval in aandeel Engels raaigras in het voorjaar van 2020 vergeleken met het voorgaande najaar, met ook een grotere terugval bij behandeling 1 en 2 vergeleken met behandelingen 5 en 6 (Fig. 11). Anders dan bij percelen 2 en 3 was er geen verschil tussen behandelingen 1 en 2 .

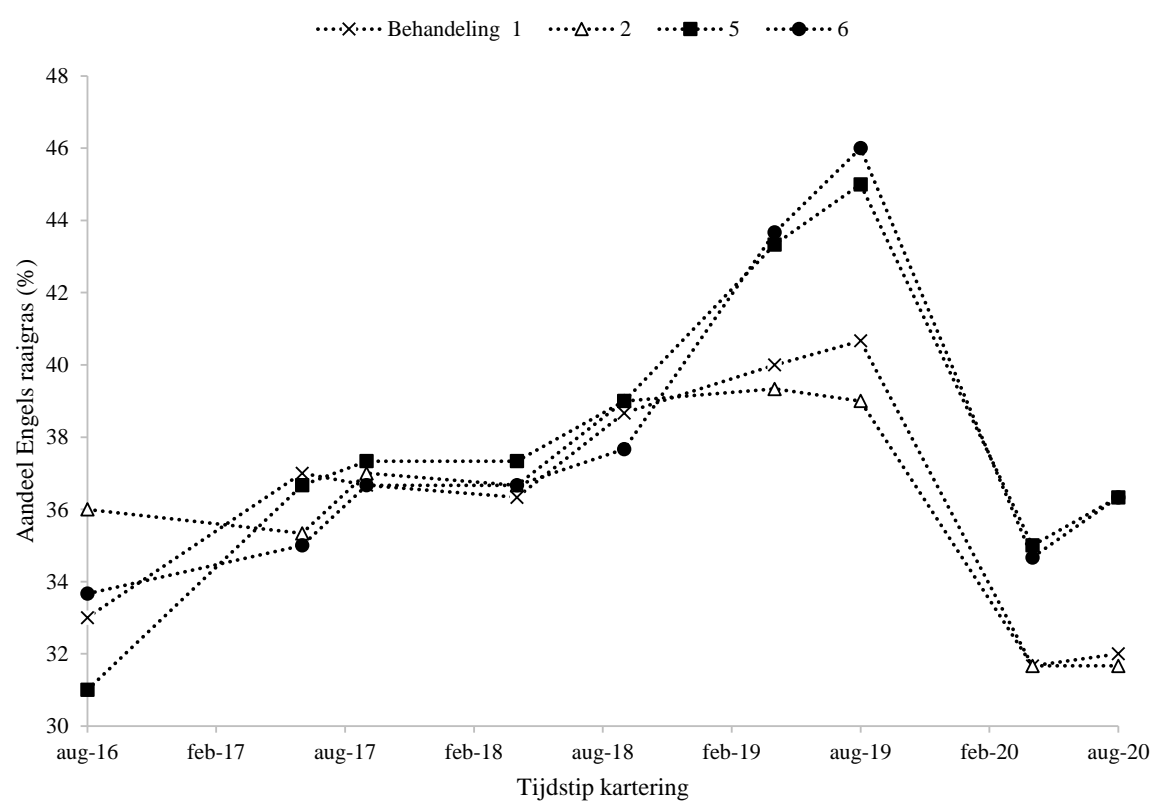

Figuur 11 Verandering in aandeel Engels raaigras (\%) over de proefperiode op perceel 4 bij behandelingen $1,2,5$, en 6 .

Op perceel 5 was het beeld anders dan op percelen $1 \mathrm{t} / \mathrm{m} 4$. Weliswaar waren de aandelen Engels raaigras in het voorjaar van 2020 afgenomen vergeleken met voorgaande zomer, maar er waren geen verschillen tussen behandelingen. 


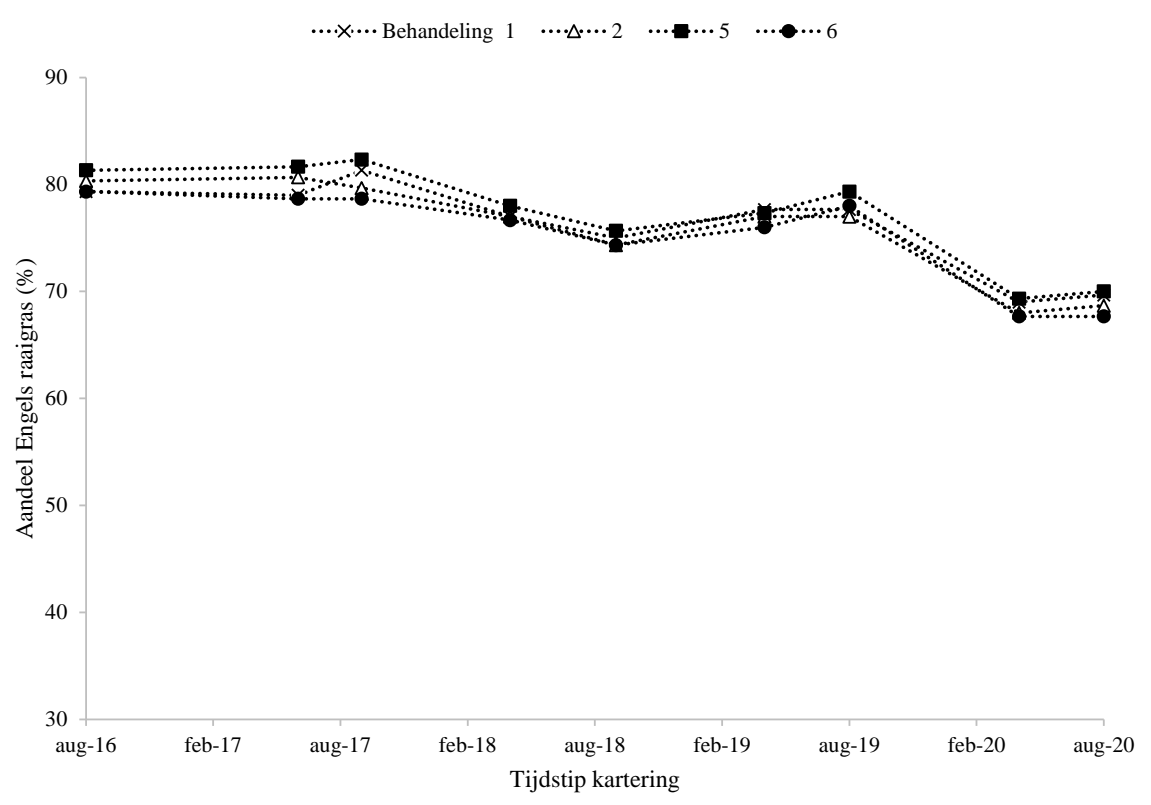

Figuur 12 Verandering in het aandeel Engels raaigras (\%) over de proefperiode op perceel 5 bij behandelingen $1,2,5$, en 6 .

Aandeel ruw beemdgras - vergelijking binnen jaren

In alle jaren verschilden de percelen significant in het aandeel ruw beemdgras in de zomer $(\mathrm{P}<$ $0,001)$. In 2016, bij start van het onderzoek, was het aandeel ruw beemdgras het hoogst op perceel 1, gevolgd door percelen 3, 4, 2, en 5 (Fig. 13). In 2017, 2018, 2019, en 2020 was deze volgorde hetzelfde, behalve dat percelen 3 en 4 van plaats wisselden. Op perceel 5 was in 2016 geen ruw beemdgras aanwezig. Vanaf 2017 nam het aandeel ruw beemdgras geleidelijk toe over de jaren.

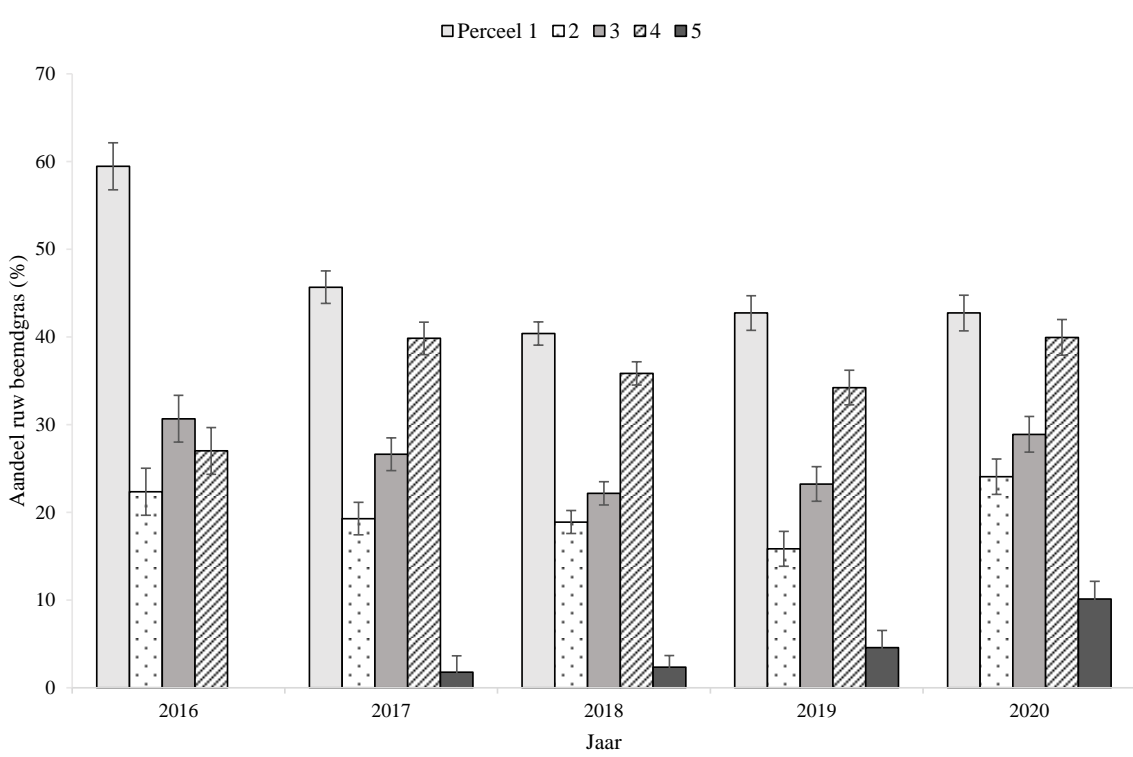

Figuur 13 Aandeel ruw beemdgras (\%) in de zomer van 2016 t/m 2020, per perceel gemiddeld over de behandelingen. Foutenbalken vertegenwoordigen de $L S D$ binnen jaren $(P<0,001)$.

In de zomers van 2016, 2017, en 2018 waren er geen significante effecten van behandeling op het aandeel ruw beemdgras ( $P>0,05)$. In de zomer van 2019 was er, naast het effect van perceel, ook een significant effect van behandeling $(P<0,001)$. Het aandeel ruw beemdgras was bij behandelingen 5 en 6 significant lager vergeleken met behandelingen $1 \mathrm{t} / \mathrm{m} \mathrm{4}$, met een gemiddeld verschil van 5,2 pp. (Tabel 18). 
Tabel 18 Aandeel ruw beemdgras (\%) in de graszode in de zomer van 2019, per behandeling gemiddeld over de percelen.

\begin{tabular}{lllllll} 
Jaar & Behandeling & & & & 5 & 6 \\
2019 & 1 & 2 & 3 & 4 & $21,3 a$ & $20,0 a$ \\
\hline
\end{tabular}

1) Een verschil in letters geeft een significant verschil aan $(P<0,001$; LSD $=2,2)$

In de zomer van 2020 was er, afhankelijk van perceel, een significant effect van behandeling op het aandeel ruw beemdgras $(P<0,05)$. Op perceel 1 was het aandeel ruw beemdgras bij behandeling 6 significant lager dan bij behandelingen $1 \mathrm{t} / \mathrm{m} \mathrm{4}$, en bij behandeling 5 significant lager dan bij behandeling 4 (Fig. 14). Op perceel 2 was het aandeel ruw beemdgras bij behandelingen 5 en 6 significant lager dan bij behandelingen $1 \mathrm{t} / \mathrm{m} 4$. Op perceel 3 was het aandeel ruw beemdgras bij behandeling 6 significant lager dan behandelingen 1 t/m 4, en bij behandeling 5 significant lager dan bij behandelingen 1 en 3. Op perceel 4 was het aandeel ruw beemdgras bij behandelingen 5 en 6 significant lager dan bij behandelingen $1 \mathrm{t} / \mathrm{m} 3$. Op perceel 5 waren er geen significante verschillen tussen behandelingen.

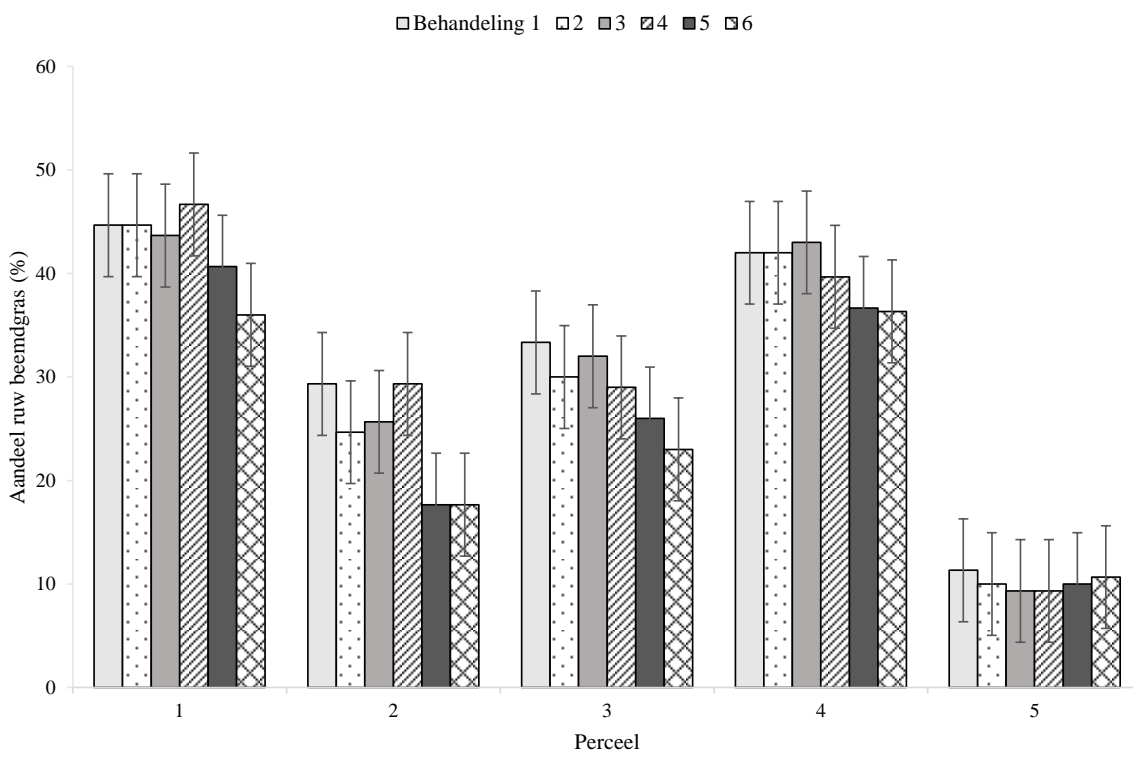

Figuur 14 Aandeel ruw beemdgras (\%) in de zomer van 2020, per perceel per behandeling. Foutenbalken vertegenwoordigen de $L S D$ binnen percelen $(P<0,05)$.

In het voorjaar van 2021 was er, afhankelijk van perceel, een aanwijzing voor een effect van behandeling op het aandeel ruw beemdgras $(P=0,06)$. Op perceel 2 was het aandeel ruw beemdgras bij behandelingen 5 en 6 mogelijk lager dan bij behandelingen 1 t/m 4, en bij behandeling 2 mogelijk lager dan bij behandeling 4 (Tabel 19). Op perceel 3 was het aandeel ruw beemdgras bij behandeling 6 mogelijk lager dan bij behandelingen 1 t/m 3, en bij behandeling 5 mogelijk lager dan bij behandeling 1 .

Tabel 19 Aandeel ruw beemdgras (\%) in de graszode van percelen 2 en 3 in het voorjaar van 2021, per perceel per behandeling.

\begin{tabular}{lllllll} 
Perceel & Behandeling & & & & \\
& 1 & 2 & 3 & 4 & 5 & 6 \\
\hline 2 & $27,7 \mathrm{bc}$ & $24,0 \mathrm{~b}$ & $26,7 \mathrm{bc}$ & $29,7 \mathrm{c}$ & $17,0 \mathrm{a}$ & $14,7 \mathrm{a}$ \\
\hline 3 & $30,0 \mathrm{c}$ & $27,7 \mathrm{bc}$ & $28,7 \mathrm{bc}$ & $26,7 \mathrm{ab}$ & $24,3 a b$ & $22,0 \mathrm{a}$ \\
\hline
\end{tabular}

1) Een verschil in letters geeft een aanwijzing voor een significant verschil binnen een perceel $(P=0,06$; LSD $=5,1)$ 


\subsection{Grasopbrengst}

\section{Opbrengstniveau}

Bij de controleveldjes (behandeling 1) varieerden de jaaropbrengsten op de vijf percelen tussen de 9,3 en 18,6 ton DS ha-1 (Fig. 15). De hoogste jaaropbrengsten werden behaald in 2017 en 2019 op perceel 1, en in het (droge) seizoen van 2018 op perceel 4. De hoogste snede-opbrengsten werden behaald in de eerste snede en waren op perceel 1 bovengemiddeld hoog (Fig. 16). Op perceel 4 werd de opbrengst van de eerste snede in 2017 negatief beïnvloed door een groot aandeel paardenbloem in de zode. Na oogst van de eerste snede verdween paardenbloem uit de zode als gevolg van chemische bestrijding.

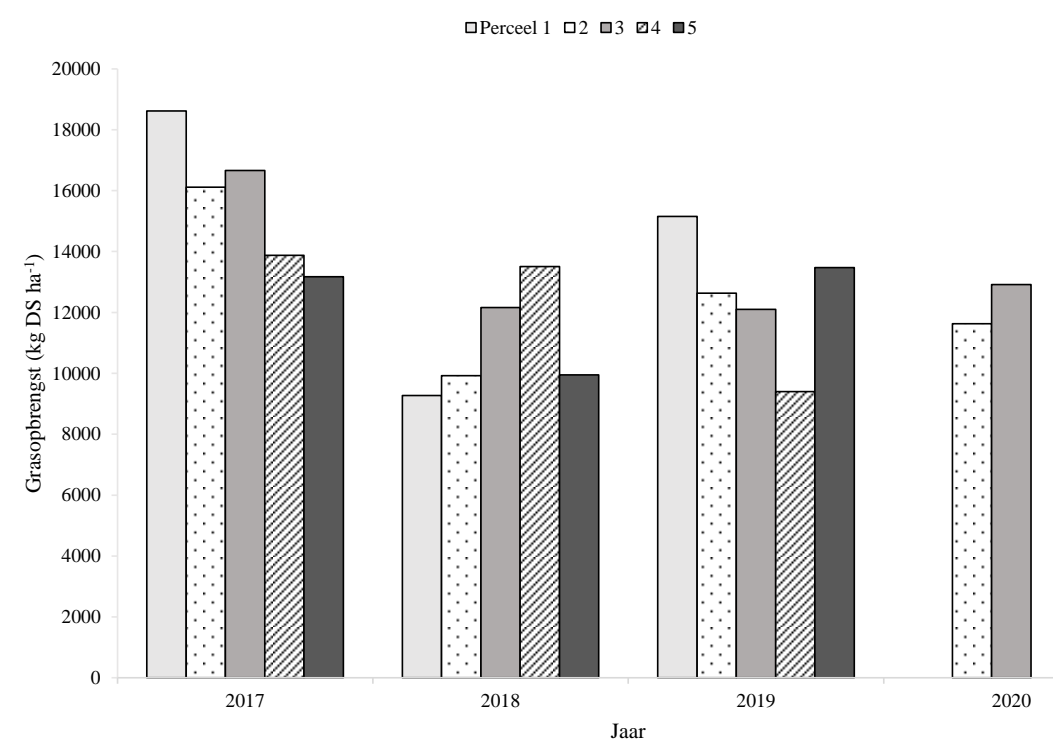

Figuur 15 Jaaropbrengsten gras op de controleveldjes tijdens de vier proefjaren, per jaar en perceel. In 2017 is bij perceel 4 de opbrengst van de tweede snede geschat; in 2020 is alleen de opbrengst van percelen 2 en 3 bepaald.

口Perceel $1 \square 2 \square 3 \square 4 \square 5$

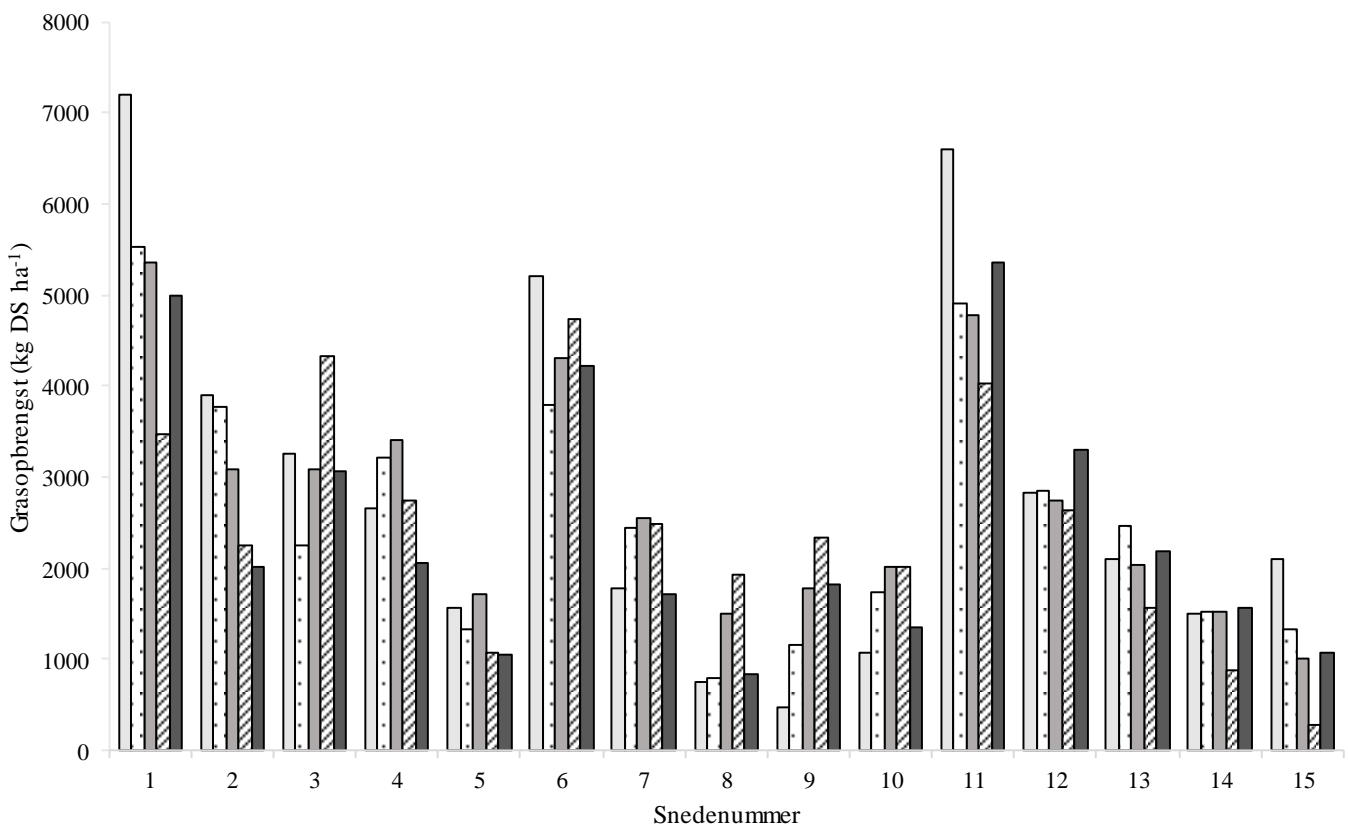

Figuur 16 Snede-opbrengsten van de controleveldjes tijdens de eerste drie proefjaren, per snedenr. en perceel. Snedenrs. 1, 6, en 11 zijn de eerste sneden van respectievelijk 2017, 2018, en 2019. Bij perceel 4 is de opbrengst van snedenr. 2 geschat. 


\section{Effect van behandeling}

In 2016 werd na het doorzaaien geen gras meer geoogst. In 2017 en 2018 was er geen significant effect van behandeling op de grasopbrengst van de eerste vier sneden (alle behandelingen) $(P>0,05)$ of alle vijf sneden (behandelingen 1 en 3 of behandelingen 1,3 , en 4$)(P>0,05)$. In 2019 was er een significant effect van behandeling op de opbrengst van de eerste vier sneden $(P<0,05)$. De opbrengst was bij behandelingen 5 en 6 significant hoger (5-9\%) dan bij behandelingen 1, 3, en 4, en was bij behandeling 2 significant hoger (5-7\%) dan bij behandelingen 1 en 3 (Tabel 20). Bij behandelingen 1, 3 , en 4 was er geen significant effect van behandeling op de opbrengst van alle vijf sneden $(P>0,05)$.

Tabel 20 Grasopbrengst ( $k g D S \mathrm{ha}^{-1}$ ) in 2019 per behandeling, gemiddeld over de eerste vier sneden van alle percelen.

\begin{tabular}{lllllll} 
& Behandeling & & & & \\
Jaar & 1 & 2 & 3 & 4 & 5 & 6 \\
\hline 2019 & $2870 a^{1)}$ & $3025 b c$ & $2831 a$ & $2900 a b$ & $3075 c$ & $3052 c$ \\
\hline
\end{tabular}

1) Een verschil in letters geeft een significant verschil aan $(P<0,05 ; L S D=140)$

In 2020 was er op percelen 2 en 3, afhankelijk van snede, een significant effect van behandeling op de grasopbrengst $(P<0,01)$. De opbrengst van de eerste snede was bij behandeling 6 significant hoger dan bij behandelingen 1 en 3, en bij behandelingen 2 en 5 significant hoger dan bij behandeling 1 (Fig. 17). Bij de tweede snede was de opbrengst bij behandeling 2 significant hoger dan bij behandelingen 1 , 3, en 4, en bij behandeling 5 significant hoger dan bij behandelingen 1 en 3 . Bij de derde snede was de opbrengst bij behandeling 5 significant hoger dan bij behandelingen $1,2,4$, en 6 , en bij behandeling 3 significant hoger dan bij behandeling 4. Bij de vierde snede was de opbrengst bij behandeling 5 significant hoger dan bij behandeling 1 . Bij de vijfde snede was de opbrengst bij behandelingen 3 significant hoger dan bij behandelingen 2, 4, 5, en 6, en bij behandeling 1 significant hoger dan bij behandelingen 2, 5, en 6 . Bij de jaaropbrengst van 2020 was er een aanwijzing voor een effect van behandeling, met mogelijk een $6-8 \%$ hogere opbrengst bij behandelingen 2 , 5, en 6 , vergeleken met behandeling $1(P=0,10)$ (Tabel 21).

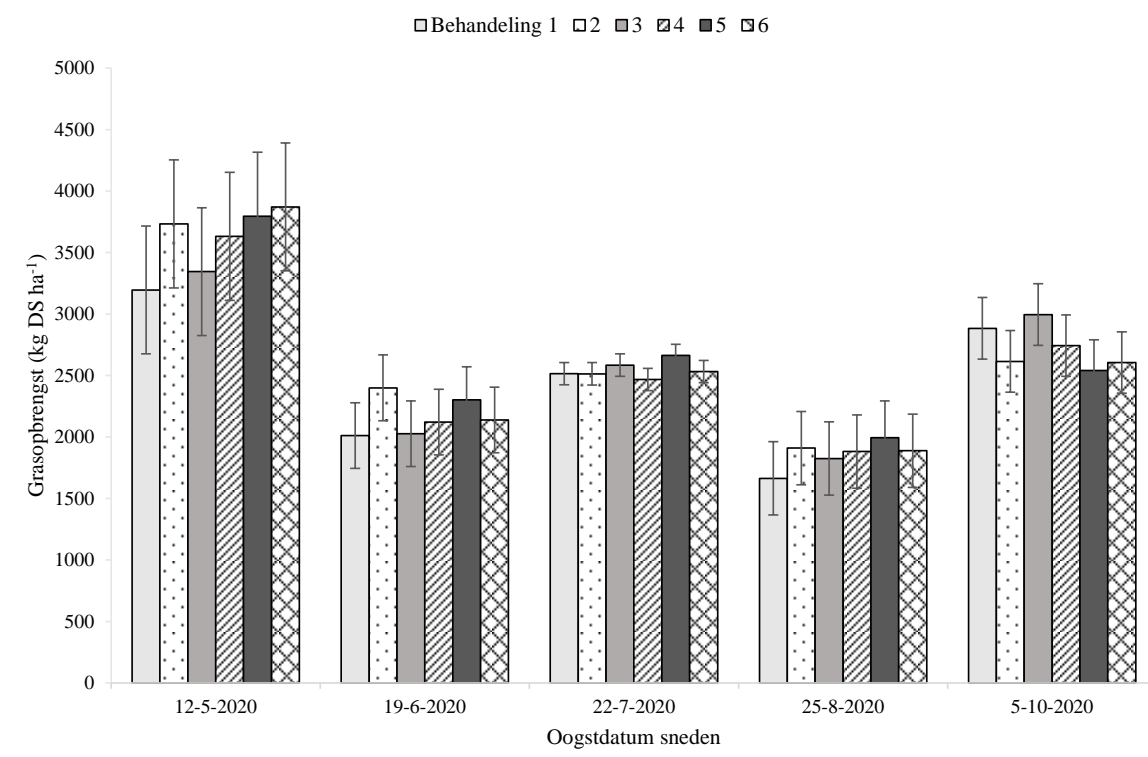

Figuur 17 Grasopbrengst in 2020 op percelen 2 en 3, per snede per behandeling. Foutenbalken vertegenwoordigen de $L S D$ binnen een snede $(P<0,01)$.

Tabel 21 Jaaropbrengst gras (kg DS ha-1) in 2020 per behandeling, gemiddeld over de percelen.

\begin{tabular}{lllllll} 
Jaar & Behandeling & & & & \\
& 1 & 2 & 3 & 4 & 6 & 6 \\
2020 & $12270 \mathrm{a}^{1)}$ & $13173 \mathrm{~b}$ & $12778 \mathrm{ab}$ & $12847 \mathrm{ab}$ & $13296 \mathrm{~b}$ & $13035 \mathrm{~b}$ \\
\hline
\end{tabular}

1) Een verschil in letters geeft een aanwijzing voor een significant verschil $(P=0,10 ; L S D=730)$ 


\subsection{Voederwaarde}

\section{Ruw as}

In 2020 was er op percelen 2 en 3 een aanwijzing voor een snede-afhankelijk effect van behandeling op het gehalte ruw as in het gras $(P=0,07)$. Bij de eerste en derde snede was er geen aanwijzing voor effecten. Bij de tweede snede was het asgehalte bij behandeling 6 mogelijk hoger dan bij behandelingen 1 , 3, en 5 , en bij behandelingen 2 en 4 mogelijk hoger dan bij behandeling 1 (Tabel 22). Bij de vierde snede was het asgehalte bij behandeling 2 mogelijk lager dan bij de andere behandelingen. Bij de vijfde snede was het asgehalte bij behandeling 5 mogelijk lager dan bij behandelingen $1,3,4$, en 6 .

Tabel 22 Ruw as ( $g \mathrm{~kg}^{-1} \mathrm{DS}$ ) in het gras in 2020, per behandeling per snede, gemiddeld over percelen 2 en 3.

\begin{tabular}{llllll} 
Behandeling & Snede & 2 & 3 & 4 & 5 \\
\hline 1 & 1 & $104 a$ & $112 \mathrm{a}$ & $122 \mathrm{~b}$ & $114 \mathrm{~b}$ \\
\hline 2 & $70 \mathrm{a}^{1)}$ & $110 \mathrm{bc}$ & $110 \mathrm{a}$ & $109 \mathrm{a}$ & $112 \mathrm{ab}$ \\
\hline 3 & $72 \mathrm{a}$ & $106 \mathrm{ab}$ & $111 \mathrm{a}$ & $119 \mathrm{~b}$ & $113 \mathrm{~b}$ \\
\hline 4 & $69 \mathrm{a}$ & $110 \mathrm{bc}$ & $110 \mathrm{a}$ & $119 \mathrm{~b}$ & $108 \mathrm{a}$ \\
\hline 6 & $71 \mathrm{a}$ & $106 \mathrm{ab}$ & $112 \mathrm{a}$ & $118 \mathrm{~b}$ & $116 \mathrm{~b}$ \\
\hline
\end{tabular}

1) Een verschil in letters geeft een aanwijzing voor een significant verschil binnen een snede $(P=0,07)$

In 2020 was er ook een snede-afhankelijk significant effect van perceel op het asgehalte $(P<0,001)$. Bij de eerste snede was het asgehalte op perceel 3 significant hoger dan op perceel 2 , en bij de tweede, derde, en vierde snede significant lager (Tabel 23).

Tabel 23 Ruw as ( $\left.\mathrm{g} \mathrm{kg}^{-1} \mathrm{DS}\right)$ in het gras in 2020 per perceel per snede, gemiddeld over behandelingen.

\begin{tabular}{llllll} 
Perceel & Snede & & & & \\
& 1 & 2 & 3 & $122 \mathrm{~b}$ & 5 \\
\hline 2 & $68 \mathrm{a}^{1)}$ & $111 \mathrm{~b}$ & $118 \mathrm{~b}$ & $113 \mathrm{a}$ & $113 \mathrm{a}$ \\
\hline 3 & $73 \mathrm{~b}$ & $105 \mathrm{a}$ & $105 \mathrm{a}$ & $113 \mathrm{a}$
\end{tabular}

1) Een verschil in letters geeft een significant verschil binnen een snede $(P<0,001)$

Verteerbaarheid van de organische stof

In 2020 was er op percelen 2 en 3 een aanwijzing voor een perceelafhankelijk effect van behandeling op de verteerbaarheid (VC-OS) van het gras $(P=0,10)$. Op perceel 2 was de VC-OS bij behandelingen 4 en 6 mogelijk hoger dan bij behandeling 3 (Tabel 24).

Tabel 24 VC-OS (\%) van het gras in 2020 per perceel per behandeling, gemiddeld over sneden.

\begin{tabular}{lllllll} 
Perceel & Behandeling & & & & \\
& 1 & 2 & 3 & 4 & 5 & 6 \\
\hline 2 & $78,1 \mathrm{ab}^{1)}$ & $78,2 \mathrm{ab}$ & $77,7 \mathrm{a}$ & $78,5 \mathrm{~b}$ & $78,3 \mathrm{ab}$ & $78,8 \mathrm{~b}$ \\
\hline 3 & $79,0 \mathrm{a}$ & $79,4 \mathrm{a}$ & $79,4 \mathrm{a}$ & $79,2 \mathrm{a}$ & $79,5 \mathrm{a}$ & $79,5 \mathrm{a}$ \\
\hline
\end{tabular}

1) Een verschil in letters geeft een aanwijzing voor een significant verschil tussen behandelingen binnen een perceel $(P=0,10)$

In 2020 was er ook een snede-afhankelijk significant effect van perceel op de VC-OS $(P=0,02)$. Bij de eerste vier sneden was de VC-OS op perceel 3 significant hoger dan op perceel 2 (Tabel 25).

Tabel 25 VC-OS (\%) van het gras in 2020 per perceel per snede, gemiddeld over behandelingen.

\begin{tabular}{|c|c|c|c|c|c|}
\hline Perceel & \multicolumn{5}{|l|}{ Snede } \\
\hline 2 & $79,8 a^{1)}$ & $77,4 a$ & $80,6 a$ & $77,3 a$ & $76,3 a$ \\
\hline 3 & $81,1 b$ & $79,1 b$ & $81,9 b$ & $78,5 b$ & $76,2 \mathrm{a}$ \\
\hline
\end{tabular}

1) Een verschil in letters geeft een significant verschil aan binnen een snede $(P=0,02)$ 
Eiwitgehalte en eiwitopbrengst

In 2020 was er op percelen 2 en 3 een aanwijzing voor een snede-afhankelijk effect van behandeling op het ruw eiwitgehalte van het gras $(P=0,08)$. Bij de eerste snede was het eiwitgehalte bij behandelingen 2, 5, en 6 mogelijk lager dan bij behandelingen 1, 3, en 4 (Tabel 26). Bij de tweede snede was er geen aanwijzing voor significante verschillen. Bij de derde snede was het eiwitgehalte bij behandelingen 2, 5, en 6 mogelijk lager dan bij behandelingen 1 en 4 . Bij de vierde snede was het eiwitgehalte bij behandeling 6 mogelijk lager dan bij behandeling 1 en 2, en bij behandelingen 3, 4, en 5 mogelijk lager dan bij behandeling 1 . Bij de vijfde snede was er geen aanwijzing voor significante verschillen.

Tabel 26 Ruw eiwit ( $g \mathrm{~kg}^{-1} \mathrm{DS}$ ) in het gras in 2020, per behandeling per snede, gemiddeld over percelen 2 en 3.

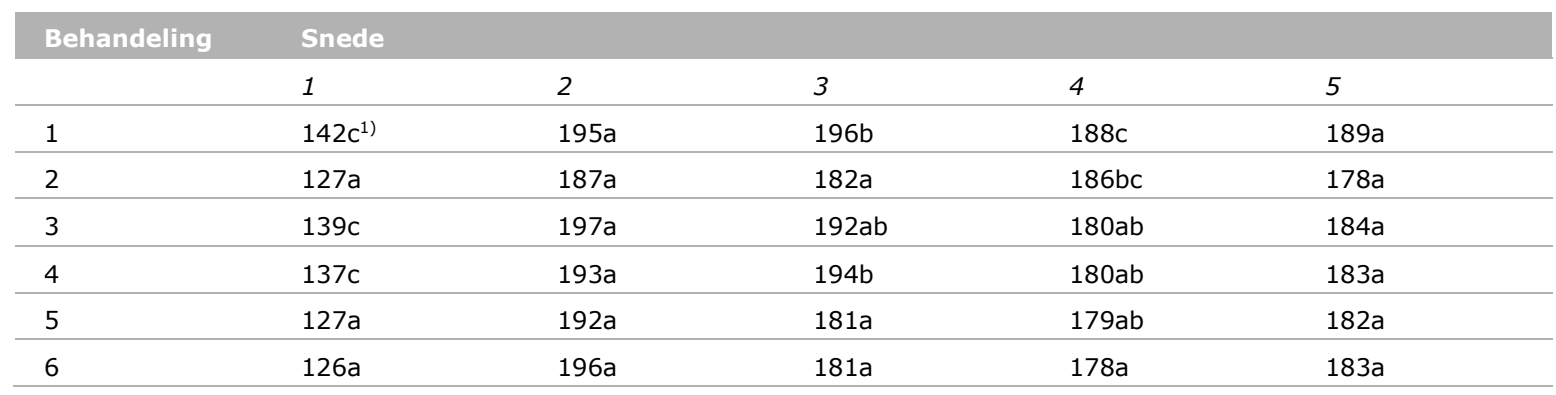

1) Een verschil in letters geeft aanwijzing voor een significant verschil tussen behandelingen binnen een snede $(P=0,08)$

In 2020 was er ook een snede-afhankelijk significant effect van perceel op het ruw eiwitgehalte $(P<$ $0,001)$, met een significant hoger eiwitgehalte van de eerste en derde snede van perceel 3 vergeleken met perceel 2 (Tabel 27). Het eiwitgehalte van de eerste snede was op perceel 2 opvallend laag.

Tabel 27 Ruw eiwit ( $\mathrm{kg}^{-1}$ DS) in het gras in 2020, per snede en perceel, gemiddeld over behandelingen.

\begin{tabular}{llllll} 
Perceel & Snede & 2 & 3 & 4 & 5 \\
\hline 2 & 1 & $193 a$ & $179 a$ & $180 a$ & $181 a$ \\
\hline 3 & $118 a^{1)}$ & $193 a$ & $196 b$ & $184 a$ & $185 a$ \\
\hline
\end{tabular}

1) Een verschil in letters geeft een significant verschil aan binnen een snede $(P<0,001)$

In 2020 was er een snede-afhankelijk significant effect van behandeling op de eiwitopbrengst $(\mathrm{P}=$ 0,03 ). Bij de eerste en vierde snede was er geen significant effect van behandeling (Tabel 28). Bij de tweede snede was de eiwitopbrengst bij behandelingen 2 en 5 significant hoger dan bij behandeling 1 , en bij behandeling 2 ook significant hoger dan bij behandeling 3. Bij snede 3 was de eiwitopbrengst bij behandelingen 1 en 3 significant hoger dan bij behandelingen 2 en 6, en bij de vijfde snede was de eiwitopbrengst bij behandelingen 1 en 3 significant hoger dan bij behandelingen 2, 5 en 6 . De jaaropbrengst eiwit in 2020 werd niet significant beïnvloed door behandeling ( $P>0,47)$.

Tabel 28 Eiwitopbrengst ( $\mathrm{kg} \mathrm{ha}^{-1}$ ) in 2020 per snede en op jaarbasis, per behandeling gemiddeld over percelen 2 en 3.

\begin{tabular}{|c|c|c|c|c|c|c|}
\hline Behandeling & \multicolumn{5}{|l|}{ Snede } & Jaar \\
\hline 1 & $461 a^{1)}$ & $388 a$ & $493 b$ & $312 a$ & $543 b$ & $2197 a$ \\
\hline 2 & $479 a$ & $450 c$ & $457 a$ & $356 a$ & $465 a$ & $2206 a$ \\
\hline 3 & $467 a$ & 399ab & $497 b$ & $329 a$ & $554 b$ & $2246 a$ \\
\hline 6 & $493 a$ & $418 a b c$ & $458 a$ & $336 a$ & $477 a$ & $2181 a$ \\
\hline
\end{tabular}

1) Een verschil in letters geeft een significant verschil aan binnen een snede of de jaaropbrengst $(P=0,03$ en $P>0,47)$ 
Suikergehalte en suikeropbrengst

In 2020 was er een significant effect van behandeling op het suikergehalte in het gras van percelen 2 en $3(P=0,001)$ en was het gehalte bij behandelingen 2,5 , en 6 significant hoger dan bij behandeling 1 (Tabel 29).

Tabel 29 Suikergehalte ( $\mathrm{g} \mathrm{kg}$-1 DS) in 2020 per behandeling, gemiddeld over de sneden van percelen 2 en 3.

\begin{tabular}{lllllll} 
& Behandeling & & & & \\
& 1 & 2 & 3 & 4 & 5 & 6 \\
Suikergehalte & $118 \mathrm{a}^{1)}$ & $128 \mathrm{~b}$ & $121 \mathrm{ab}$ & $125 \mathrm{ab}$ & $129 \mathrm{bc}$ & $129 \mathrm{~b}$ \\
\hline
\end{tabular}

1) Een verschil in letters geeft een significant verschil aan $(P=0,001)$

In 2020 was er ook een snede-afhankelijk significant effect van perceel op het suikergehalte $(P<$ 0,001 ), met een significant hoger suikergehalte bij snede 1 , 2, en 4 op perceel 3 vergeleken met perceel 2 (Tabel 30).

Tabel 30 Suikergehalte ( $g \mathrm{~kg}^{-1}$ DS) in 2020 per perceel per snede, gemiddeld over behandelingen.

\begin{tabular}{llllll} 
Perceel & Snede & 2 & 3 & 4 & 5 \\
\hline 2 & 1 & $85 a$ & $127 a$ & $75 a$ & $93 a$ \\
\hline 3 & $240 b^{1)}$ & $109 b$ & $130 a$ & $97 b$ & $87 a$ \\
\hline
\end{tabular}

1) Een verschil in letters geeft een significant verschil aan binnen een snede $(P<0,001)$

Bij de suikeropbrengst was er significant effect van behandeling $(P<0,001)$ en een aanwijzing voor een snede-afhankelijk effect van behandeling $(P=0,05)$. Bij het hoofdeffect van behandeling was de suikeropbrengst bij behandelingen 2, 5, en 6 significant hoger dan bij behandelingen 1 en 3 , en bij behandelingen 3 en 4 significant hoger dan bij behandeling 1 (Tabel 31). Bij de aanwijzing voor een snede-afhankelijk effect was bij de eerste snede was de suikeropbrengst bij behandeling 6 mogelijk hoger dan bij behandelingen 1, 3, en 4, bij behandelingen 2 en 5 mogelijk hoger dan bij behandelingen 1 en 3, en bij behandeling 4 mogelijk hoger dan bij behandeling 1 (Tabel 31). Bij de tweede snede was de suikeropbrengst bij behandelingen 2 en 5 mogelijk hoger dan bij behandelingen 1 en 3 en bij behandelingen 4 en 6 mogelijk hoger dan bij behandeling 1 . Bij de derde snede was de suikeropbrengst bij behandeling 5 mogelijk hoger dan bij behandelingen 1 en 3. Bij de vierde snede was de suikeropbrengst bij behandelingen $2 \mathrm{t} / \mathrm{m} 6$ mogelijk hoger dan bij behandeling 1 . Bij de vijfde snede was de suikeropbrengst bij behandeling 5 mogelijk lager dan bij behandeling 3 .

Tabel 31 Suikeropbrengst ( $\left.\mathrm{kg} \mathrm{ha}^{-1}\right)$ in 2020 per snede per behandeling, gemiddeld over percelen 2 en 3.

\begin{tabular}{|c|c|c|c|c|c|c|}
\hline Behandeling & \multicolumn{5}{|l|}{ Snede } & Gem. \\
\hline 1 & $664 a^{1)}$ & $188 a$ & $311 a$ & $132 a$ & $241 a b$ & $307 a$ \\
\hline 2 & $847 \mathrm{~cd}$ & $238 c$ & $338 a b$ & $166 b$ & $235 a b$ & $365 c$ \\
\hline 3 & $705 a b$ & 194ab & $313 a$ & $160 b$ & $270 b$ & $328 b$ \\
\hline 6 & $906 d$ & $210 b c$ & $329 a b$ & $167 b$ & $243 a b$ & $371 c$ \\
\hline
\end{tabular}

1) Een verschil in letters geeft een aanwijzing voor een significant verschil binnen een snede $(P=0,05)$ of geeft een significant verschil aan binnen het gemiddelde van behandeling $(P<0,001)$

In 2020 was er ook een snede-afhankelijk significant effect van perceel op suikeropbrengst $(P<$ $0,001)$, met een significant hogere suikeropbrengst bij snede 2 en 4 op perceel 3 vergeleken met perceel 2 (Tabel 32). 
Tabel 32 Suikeropbrengst $\left(\mathrm{kg} \mathrm{ha}^{-1}\right)$ in 2020 per perceel per snede, gemiddeld over behandelingen.

\begin{tabular}{llllll} 
Perceel & Snede & 2 & 3 & 4 & 5 \\
\hline 2 & 1 & $171 \mathrm{a}$ & $324 \mathrm{a}$ & $138 \mathrm{a}$ & $249 \mathrm{a}$ \\
\hline 3 & $808 \mathrm{a}$ & $253 \mathrm{~b}$ & $332 \mathrm{a}$ & $183 \mathrm{~b}$ & $240 \mathrm{a}$ \\
\hline
\end{tabular}

1) Een verschil in letters geeft een significant verschil aan binnen een snede $(P<0,001)$

Bij de jaaropbrengst suiker was er een significant effect van behandeling $(P<0,001)$. De jaaropbrengst was bij behandeling 5 significant hoger dan bij behandelingen 1 , 3, en 4, bij behandelingen 2 en 6 significant hoger dan bij behandelingen 1 en 3, en bij behandeling 4 significant hoger dan bij behandeling 1 (Tabel 33).

Tabel 33 Jaaropbrengst suiker $\left(\mathrm{kg} \mathrm{ha}^{-1}\right)$ in 2020 per behandeling, gemiddeld over percelen 2 en 3.

\begin{tabular}{lllllll} 
Jaar & Behandeling & & & & \\
& 1 & 2 & 3 & 4 & 5 & 6 \\
\hline 2020 & $1536 \mathrm{a}$ & $1824 \mathrm{~cd}$ & $1641 \mathrm{ab}$ & $1740 \mathrm{bc}$ & $1881 \mathrm{~d}$ & $1856 \mathrm{~cd}$ \\
\hline
\end{tabular}

1) Een verschil in letters geeft een significant verschil aan $(P<0,001)$ 


\section{$4 \quad$ Discussie}

\subsection{Aantal kiemplanten}

\section{Vochttoestand van de toplaag}

Het gemiddelde aantal kiemplanten was in 2018 hoger dan in 2016 en 2017, en in 2019 aanzienlijk hoger dan in de drie voorgaande jaren. Deze verschillen kunnen worden verklaard uit verschillen in vochttoestand van de grond tijdens en na het doorzaaien. In 2016 werd doorgezaaid in een droge toplaag en viel er pas na 15 dagen neerslag van betekenis (Fig. 1). Het kleine aantal kiemplanten in dat jaar kan daarom worden verklaard uit een vochttekort tijdens de kieming. De verwachting destijds, dat het gezaaide zaad in de grond zou overleven en na regenval alsnog zou kiemen, is maar beperkt uitgekomen. Een deel van de zaden is mogelijk wel gekiemd, bijvoorbeeld door vochtopname uit dauw, maar vervolgens uitgedroogd en gestorven. Bij een ander deel van het zaad is mogelijk de kiemkracht verloren gegaan onder de invloed van zonlicht, omdat de zaaisneden deels open waren blijven staan. In 2017 was er geen vochttekort; er werd doorgezaaid in een natte toplaag en na doorzaaien viel er regelmatig regen (Fig. 2). Desondanks werden weinig kiemplanten geteld. Een aanzienlijk deel van de zaden of jonge kiemplanten is mogelijk gestorven als gevolg van zuurstofgebrek. In 2018 werd doorgezaaid in een voldoende vochtige toplaag, maar werd het moment van doorzaaien gevolgd door een droge periode (Fig. 3). De ingelaste beregening is waarschijnlijk de oorzaak geweest van het hogere aantal kiemplanten in het (droge) najaar van 2018 vergeleken met het (droge) najaar van 2016. In 2019 werd doorgezaaid in een vochtige toplaag en viel er regelmatig regen na de opkomst van de eerste kiemplanten. Daarnaast werden de doorgezaaide veldjes na het doorzaaien extra gerold. Dit extra rollen is waarschijnlijk de belangrijkste oorzaak geweest van het hoge aantal kiemplanten in 2019. Door het extra rollen waren de zaaisneden in 2019 volledig gesloten, terwijl deze in voorgaande jaren deels openbleven. Bij volledige sluiting is er maximaal contact tussen de zaden en omringende grond, en daarmee maximale vochtaanvoer. Uit de ervaringen na vier keer doorzaaien in het najaar, onder wisselende omstandigheden, wordt geconcludeerd dat doorzaaien in een droge of natte toplaag moet worden vermeden. Voor een maximale opkomst van kiemplanten is het noodzakelijk om door te zaaien in een voldoende vochtige toplaag, bij verwachting van regelmatig regenval, en ervoor te zorgen dat de zaaisneden volledig zijn gesloten (Bijlage).

\section{Openheid van de zode bij doorzaaien}

In de twee jaren waarin de openheid van de zode direct na doorzaaien werd gemeten, 2018 en 2019, nam alleen in 2019 de totale bezetting door de zode af als gevolg van voorbehandeling (spuiten, kort afmaaien, wiedeggen), en alleen op percelen 1, 3, en 4. Ondanks dat voorbehandeling op perceel 5 geen effect had op de totale bezetting was, bij een hogere bezettingsgraad (Tabel 5), het aantal kiemplanten op perceel 5 hoger dan op perceel 4 (Tabel 4). Een mogelijke verklaring voor deze paradox is dat totale bezetting geen absolute maat is voor de openheid van de zode. Twee percelen met dezelfde bezetting (aantal spruiten per $\mathrm{m}^{2}$ ) kunnen toch een verschil in openheid hebben. Perceel 5 had tijdens de proefperiode bijna altijd de maximale gemeten bezetting ( $98 \%$ ), maar de zode was op het oog meestal opener dan op de andere percelen. Het verschil in openheid kan mogelijk worden verklaard door het verschil in aandeel ruw beemdgras, een grassoort waarvan de spruiten minder rechtop groeien dan bijvoorbeeld de spruiten van Engels raaigras. Het aandeel ruw beemdgras was het laagst op perceel 5 en het hoogst bij percelen 1, 4, en 3 (Fig. 13). Mogelijk heeft op perceel 5 het relatief hoge aandeel timotheegras (Tabel 15) ook bijgedragen aan de relatieve openheid van de zode.

\section{Spuiten tegen ruw beemdgras}

Uit vergelijking van het aantal kiemplanten tussen behandeling 5 (spuiten) en 6 (niet spuiten) wordt geconcludeerd dat spuiten tegen ruw beemdgras in 2016 en 2019 geen effect had op het aantal kiemplanten. In 2017, het jaar waarin vanwege natheid niet werd geëgd, was het aantal kiemplanten op percelen 2, 3, en 4 bij behandeling 5 hoger dan bij behandeling 6, en daarmee hoger als gevolg van spuiten (Tabel 3). In 2018 gaf spuiten alleen een hoger aantal kiemplanten op perceel 3 . Wanneer naast spuiten ook werd geëgd (in 2016, 2018, en 2019) had spuiten vrijwel geen effect op het aantal kiemplanten. 
Effect van perceel

Het aantal kiemplanten was in 2017 op perceel 5 duidelijk hoger dan op de andere percelen, in 2018 hoger op perceel 1 en 5 vergeleken met de meeste andere percelen, en in 2019 duidelijk hoger op perceel 1 vergeleken met de andere percelen. Het hogere aantal kiemplanten op perceel 5 in 2017, bij doorzaai onder natte omstandigheden, wordt verklaard uit de relatief drogere toplaag van dit perceel

(Tabel 2). De tendens tot meer kiemplanten op perceel 1, en in mindere mate ook op perceel 5, wordt verklaard uit een meer open zode op beide percelen tijdens het doorzaaien. Op perceel 1 werd dit veroorzaakt door meer open plekken (deels door droogteschade) en op perceel 5 door een meer open zode.

\subsection{Botanische samenstelling}

\section{Bezetting door de graszode}

Behandeling in het najaar had weinig effect op de bezetting door de graszode in de volgende zomer, behalve in de zomer van 2019 op de percelen 3 en 4 (Tabel 11). Op perceel 3 werd de significant lagere bezetting bij behandeling 1 veroorzaakt door een $2 \mathrm{pp}$. lagere bezetting bij een van de drie herhalingen en was daarmee geen effect van behandeling maar het gevolg van een uitschieter. Op perceel 4 kan uit een onderlinge vergelijking van behandelingen 2, 5, en 6 en behandelingen 1, 3, en 4 worden afgeleid dat de hogere bezetting bij behandelingen 2, 5, en 6 werd veroorzaakt door behandeling in het najaar van 2018. Behandelingen 2, 5 en 6 waren identiek, behalve dat er bij behandeling 2 niet was doorgezaaid en bij behandeling 6 niet was gespoten tegen ruw beemdgras. Omdat de hogere bezetting niet alleen aanwezig was bij behandelingen 5 en 6, maar ook bij behandeling 2, was de hogere bezetting niet het gevolg van doorzaaien maar van voorbehandeling.

In de zomer van 2018 en 2020 waren er effecten van perceel op de bezetting. In de zomer van 2018 werd de lagere bezetting op perceel 1 veroorzaakt door droogteschade op meerdere veldjes. De lagere bezetting op percelen 1 en 5 in de zomer van 2020 kan ook worden verklaard door droogteschade, omdat percelen 1 en 5 minder vochthoudend waren dan de andere percelen (Tabel 2). De aanzienlijk lagere bezetting op perceel 4 in de zomer van 2020 was waarschijnlijk het gevolg van relatief grote muizenschade in de winter van 2019 op 2020. Hierdoor was in het voorjaar van 2020 de bezetting op perceel 4 (gem. 94,5\%) aanzienlijk lager dan op de andere percelen (gem. 97,0-97,6\%), en in de zomer was er nog steeds een verschil met de andere percelen.

\section{Aandeel Engels raaigras}

Doorzaai in het najaar van 2018 gaf de volgende zomer op alle percelen een hoger aandeel Engels raaigras bij behandelingen 5 en 6 vergeleken met behandelingen $1 \mathrm{t} / \mathrm{m} 4$. De gemiddelde toename bij behandelingen 5 en 6 was bij perceel 5 (1,5 pp.) veel kleiner dan bij de andere percelen (5,3 - 6,9 pp.). Een verklaring hiervoor is de al hoge bezetting met Engels raaigras en timotheegras op perceel 5 , respectievelijk gemiddeld $75 \%$ en $23 \%$ (totaal $98 \%$ ) in de zomer van 2018 . In de praktijk zou perceel 5 vanwege de al uitstekende botanische samenstelling niet worden doorgezaaid. Voor een meer representatieve beoordeling van het gemiddelde effect van doorzaaien in 2018 op het aandeel Engels raaigras in 2019 kan perceel 5 daarom beter uit het gemiddelde worden gelaten. De gemiddelde toename van aandeel Engels raaigras is dan 6,1 in plaats van 5,1 pp.

Door de zware muizenvraat in de winter van 2019 op 2020 was het niet mogelijk een betrouwbaar beeld te krijgen van het effect van doorzaaien in het najaar van 2019 op het aandeel Engels raaigras in de zomer van 2020. Als gevolg van de muizenschade was het aandeel Engels raaigras in de zomer van 2020 op alle percelen lager dan in de zomer van 2019. Bij percelen $1 \mathrm{t} / \mathrm{m} 4$ was het aandeel Engels raaigras bij behandeling 6 of behandelingen 5 en 6 meestal hoger dan bij behandelingen $1 \mathrm{t} / \mathrm{m}$ 4 (Fig. 7).

Op perceel 2 was het aandeel Engels raaigras ook bij behandeling 2 duidelijk hoger dan bij behandelingen 1, 3, en 4 . Bij behandelingen 2, 5, en 6 was het aandeel Engels raaigras in de zomer van 2020 respectievelijk 10, 14, en 17 pp. hoger dan bij behandeling 1. Behandelingen 2, 5 en 6 waren identiek, behalve dat er bij behandeling 2 niet was doorgezaaid en bij behandeling 6 niet was gespoten tegen ruw beemdgras. Uit de verschillen tussen deze behandelingen kan daarom worden 
afgeleid dat het hogere aandeel Engels raaigras bij behandelingen 5 en 6 deels werd veroorzaakt door voorbehandeling (10 pp.) en deels door doorzaaien in voorgaande jaren (respectievelijk 4 en 7 pp.). In 2019 werd na uitvoer van de behandelingen waargenomen dat de muizen de behandelde veldjes meden. Een verklaring hiervoor is dat kort afmaaien en eggen leidt tot een lagere beschutting van de muizen door de zode tijdens de winter. De grootste bijdrage is waarschijnlijk geleverd door eggen, omdat daarmee een deel van de strooisellaag voor langere tijd wordt verwijderd. Door het mijden van voorbehandelde veldjes is op deze veldjes blijkbaar ook de vraatschade lager geweest, waardoor op deze veldjes het aandeel Engels raaigras minder afnam.

Op percelen 1, 3, 4, en 5 was er in de zomer van 2020 geen verschil in aandeel Engels raaigras tussen behandeling 2 en behandeling 1. Op deze percelen had voorbehandeling in voorgaande jaren dus geen effect op het aandeel Engels raaigras in 2020, en hogere aandelen Engels raaigras bij behandelingen 5 en 6 in 2020 waren daarmee volledig het gevolg van doorzaaien in voorgaande jaren. Dit effect kan worden geschat op 2-4 pp., 7-9 pp., 4 pp., en -2-0 pp. voor respectievelijk percelen 1, 3, 4, en 5, en komt grotendeels overeen met het effect van doorzaaien in 2018 op het aandeel Engels raaigras in 2019. Het is verder aannemelijk dat in de winter van 2019 op 2020 de jonge kiemplanten, afkomstig van doorzaai in het voorgaande najaar, als eerste door de muizen zijn afgevreten, omdat jonge planten doorgaans smakelijker zijn dan oude planten. Daarentegen waren de kiemplanten uit 2018 inmiddels ruim een jaar oud, waardoor het minder waarschijnlijk is dat deze planten nog steeds smakelijker waren dan al bestaande planten, en disproportioneel werden aangevreten. Uit de bovenstaande combinatie van waarnemingen volgt dat de verbetering van het aandeel Engels raaigras in 2019, als gevolg van doorzaai in 2018, in 2020 waarschijnlijk grotendeels intact is gebleven, maar dat de kiemplanten uit het najaar van 2019 in het voorjaar van 2020 waarschijnlijk volledig waren gestorven. De voorkeur van de muizen (kleine grazers) voor bepaalde plantensoorten blijkt ook uit verschillen in botanische samenstelling tussen de zomer van 2019 en het voorjaar van 2020. Terwijl het aandeel Engels raaigras duidelijk afnam als gevolg van vraat (evenals de schaars aanwezige paardenbloem), waren de aandelen kweekgras, timotheegras, en zachte dravik onveranderd (Tabel 17). De aandelen ruw beemdgras en straatgras namen toe. Dit suggereert enerzijds dat de muizen deze soorten minder of niet vraten, maar kan (deels) ook veroorzaakt zijn doordat deze soorten de open plekken in een zode in korte tijd kunnen innemen, als gevolg van een snelle kieming van in de grond aanwezige zaden.

Tussen de zomer van 2016 en de zomer van 2019 nam het aandeel Engels raaigras toe (en het aandeel ruw beemdgras af) op percelen 1, 3, en 4 . Deze toename zou veroorzaakt kunnen zijn door een relatief sterkere afname van het aandeel ruw beemdgras, vergeleken met Engels raaigras, in de droge zomers van 2018 en 2019. Het verloop van het aandeel Engels raaigras tussen het voorjaar van 2018 en de zomer van 2019, en tussen het voorjaar van 2019 en de zomer van 2019, geeft echter geen aanleiding dit te veronderstellen. Weliswaar nam tussen het voorjaar en de zomer van 2018 het aandeel ruw beemdgras gemiddeld wat meer af (-2,3 pp.) dan het aandeel Engels raaigras (-0,3 pp.) (Fig. 8 t/m 12), maar tussen de zomer van 2018 en het voorjaar van 2019 werd deze afname weer ongedaan gemaakt (ruw beemdgras $+2,2 \mathrm{pp}$., Engels raaigras $+1,1 \mathrm{pp}$.). Tussen het voorjaar van 2019 en de zomer van 2019 bleef het aandeel Engels raaigras gelijk of nam licht toe, terwijl het aandeel ruw beemdgras gelijk bleef of licht afnam. Uit de verschillen in aandeel Engels raaigras tussen de zomer van 2016 en de zomer van 2019, op percelen 1, 3, en 4, blijkt dat het aandeel Engels raaigras ook kan worden verhoogd door het type beheer, in dit geval alleen bemesten met kunstmest, alleen maaien, en zwaar maaien van de eerste snede.

\section{Aandeel ruw beemdgras}

In de zomer van 2019 en 2020 was het aandeel ruw beemdgras meestal lager bij behandelingen 5 en 6, vergeleken met behandelingen $1 \mathrm{t} / \mathrm{m} 4$ (Tabel 18, Fig. 14). Bij behandeling 2 was het aandeel ruw beemdgras echter niet lager vergeleken met behandelingen 1, 3, en 4. Behandelingen 2, 5 en 6 waren identiek, behalve dat er bij behandeling 2 niet was doorgezaaid en bij behandeling 6 niet was gespoten tegen ruw beemdgras. Uit onderlinge vergelijking van deze drie behandelingen volgt daarom dat spuiten en eggen alleen een lager aandeel ruw beemdgras geeft als dit wordt gecombineerd met doorzaaien (behandelingen 5 en 6). Zonder doorzaaien (behandeling 2) wordt de ontstane ruimte weer opgevuld door ruw beemdgras. In de zomer van 2019 correspondeerde de toename van aandeel Engels raaigras op de vorig najaar doorgezaaide veldjes (Tabel 13) vrijwel volledig met de afname van 
het aandeel ruw beemdgras (Tabel 18). Uit het ontbreken van een verschil in aandeel ruw beemdgras tussen behandeling 5 en 6 in 2019 kan verder worden geconstateerd dat in 2018 spuiten geen extra effect gaf vergeleken met alleen eggen. Gecombineerd met de effecten van spuiten en eggen op het aantal kiemplanten wordt geconcludeerd dat, mits uitgevoerd onder voldoende droge omstandigheden, wiedeggen niet minder effectief is dan spuiten tegen ruw beemdgras.

\subsection{Grasopbrengst}

Het ontbreken van een effect van doorzaaien in het najaar van 2016 en 2017 op de grasopbrengst in respectievelijk 2017 en 2018 wordt verklaard uit een te laag aantal kiemplanten, waardoor doorzaaien geen effect had op het aandeel Engels raaigras in het volgende jaar. In 2019 leek het hogere aandeel Engels raaigras, als gevolg van geslaagde doorzaai in 2018 , zich te vertalen in de 5-9\% hogere grasopbrengst bij behandelingen 5 en 6 , vergeleken met behandelingen 1, 3, en 4 . Echter, tussen behandeling 2 en behandeling 1 was er een vergelijkbaar verschil (Tabel 20) terwijl er bij behandeling 2 niet was doorgezaaid en het aandeel Engels raaigras bij deze behandeling niet verschilde van behandeling 1 (Tabel 13). Hieruit wordt geconcludeerd dat de hogere opbrengst bij behandelingen 2, 5, en 6 in 2019 voornamelijk het gevolg was van voorbehandeling, in plaats van doorzaaien, in 2018. In 2020 was het beeld op percelen 2 en 3 deels vergelijkbaar met 2019; de jaaropbrengst bij behandelingen 2, 5, en 6 was mogelijk 6-8\% hoger vergeleken met behandeling 1 . Uit onderlinge vergelijking van behandelingen 2, 5, en 6 blijkt dat dit effect ook niet het gevolg was van doorzaaien, maar van voorbehandeling. Opvallend is dat er geen aanwijzing was voor significante verschillen tussen behandelingen 2, 5 en 6, en behandelingen 3 en 4. Dit suggereert dat voorbehandeling in 2016 en 2017 ook in 2020 nog een positief effect had op de opbrengst. De positieve effecten van voorbehandeling op de opbrengst worden verklaard uit een lagere muizenschade op voorbehandelde veldjes. Doordat behandelde veldjes door de muizen werden gemeden, was op deze veldjes de vraatschade aan de stoppels lager, konden deze veldjes zich het volgende voorjaar sneller herstellen, hoefde er minder opbrengst in dit herstel te worden geïnvesteerd, en was daardoor de gemaaide opbrengst hoger.

\subsection{Voederwarde}

\section{Ruw as}

De aanwijzing voor snede-afhankelijke significante verschillen tussen behandelingen in gehalte ruw as in 2020 lijkt niet van structurele betekenis en vooral het gevolg van enkele losse verschillen. De gemiddelde asgehalten per snede kwamen overeen met de landelijke gemiddelden voor vers gras op kleigrond van 99, 115, en $112 \mathrm{~g} \mathrm{~kg}^{-1}$ DS voor vers gras respectievelijk gemaaid voor 12 juni, tussen 21 juni en 21 augustus, en na 21 augustus (CVB, 2021). Uit de resultaten kan niet worden geconcludeerd dat behandeling of het niveau van muizenschade effect hadden op het gehalte ruw as van het gemaaide gras.

\section{Verteerbaarheid}

Behandeling in de periode 2016 t/m 2019 had op percelen 2 en 3 geen duidelijk effect op de VC-OS in 2020. Verschillen van 5 tot $12 \mathrm{pp}$. in aandeel ruw beemdgras tussen behandelingen 5 en 6 en behandeling 1 (Fig. 14) leidden niet tot een verschil in VC-OS (Tabel 24). Verder was de gemiddelde VC-OS op perceel 3 hoger dan op perceel 2 (Tabel 25), ondanks een gemiddeld 5 pp. hoger aandeel ruw beemdgras op perceel 3 (Fig. 14). Uit de voorliggende resultaten kan daarom niet worden geconcludeerd dat het aandeel ruw beemdgras in de zode een negatief effect had op de VC-OS.

\section{Eiwitgehalte en eiwitopbrengst}

Uit de vergelijking van eiwitgehalte (Tabel 26) en eiwitopbrengst (Tabel 28) tussen behandelingen 2, 5, en 6 kan niet worden geconcludeerd dat doorzaaien in 2018 en 2019 heeft geleid tot een hoger eiwitgehalte of een hogere eiwitopbrengst in 2020. Verschillen in eiwitgehalte worden verklaard uit het effect van verschillen in muizenschade op de opbrengst. Behandelingen met minder muizenschade tijdens de voorgaande winter (Tabel 6) hadden in het voorjaar een hogere opbrengst (Tabel 21), waardoor bij een vergelijkbaar niveau van stikstofopname (c.q. eiwitopbrengst, Tabel 28) het 
eiwitgehalte werd verdund. Hierdoor waren de eiwitgehalten in de eerste snede het laagst bij de behandelingen met de minste schade. Dit effect speelde in geringere mate ook nog in de tweede en vierde snede. In de derde snede correspondeerden de lagere eiwitgehalten bij de behandelingen met de minste muizenschade niet met een hogere opbrengst. Dit was mogelijk het gevolg van de hogere stikstofopname (c.q. eiwitopbrengst) in de eerste twee sneden, waardoor de hoeveelheid reststikstof uit vorige bemesting lager was op deze veldjes. In de vijfde snede leek dit effect opnieuw te spelen. Door dergelijke compensatie-effecten over opeenvolgende sneden (De Boer et al., 2018) was er uiteindelijk geen effect van de behandelingen of de muizenschade op de stikstofbenutting (c.q. jaaropbrengst eiwit).

\section{Suikergehalte en suikeropbrengst}

Uit vergelijking van behandeling 2 met behandelingen 5 en 6 wordt geconcludeerd dat doorzaaien in de periode 2016 t/m 2019 niet heeft geleid tot een hoger suikergehalte of een hogere suikeropbrengst in 2020. Uit vergelijking van behandelingen 2, 5, en 6 met behandelingen 1, 3, en 4 blijkt dat voorbehandeling in deze periode wel duidelijke effecten had op het suikergehalte en de suikeropbrengst in 2020. De grootste effecten werden gerealiseerd met voorbehandeling in 2018 en 2019, maar voorbehandeling in 2016 en 2017 (behandeling 4) gaf in 2020 ook een significant hogere suikeropbrengst vergeleken met behandeling 1 . De suikeropbrengst bij behandeling 3 verschilde niet significant met behandeling 1, maar wat opvalt is dat bij behandeling 3 de suikeropbrengst met 100 $\mathrm{kg} \mathrm{ha}^{-1}$ verschilde van behandeling 1 , en bij behandeling 4 met $200 \mathrm{~kg} \mathrm{ha}^{-1}$. Dit suggereert een cumulatief effect van $100 \mathrm{~kg}$ suiker ha-1 extra per behandelingsjaar. De effecten bij behandelingen 3 en 4, vooral op perceel 2, zijn waarschijnlijk vooral het gevolg geweest van verwijdering van een deel van de strooisellaag door eggen (in 2016 en 2017) op de vraatschade door muizen (zie boven). De lagere eiwitgehalten bij behandelingen 2, 5, en 6 hebben mogelijk ook bijgedragen aan de hogere suikergehalten en suikeropbrengsten van deze behandelingen, gelet op de negatieve relatie tussen ruw eiwitgehalte en suikergehalte in gras (Bryant et al., 2012; Delagarde et al., 2000).

\subsection{Muizenschade}

Het voorliggende onderzoek laat zien dat eggen de negatieve effecten van muizenvraat op het aandeel Engels raaigras, de grasopbrengst, en het suikergehalte, kan verminderen. Het is onbekend in hoeverre het mijden van de voorbehandelde veldjes door de muizen een kwestie was van voorkeur of van noodzaak tot overleven. In het eerste geval is de vraag of het eggen van hele percelen hetzelfde effect gaat hebben als het eggen van kleine veldjes, die door de muizen makkelijk kunnen worden vermeden in een verder onbehandeld perceel. Wanneer bij eggen van het hele perceel, en daardoor mogelijk een gebrek aan uitwijkmogelijkheden, de muizen een mindere beschutting wel accepteren en aanwezig blijven, wordt het perceel alsnog afgevreten. Als een gedwongen verblijf van de muizen op een geëgd perceel leidt tot een hogere sterfte, dan zou perceelbehandeling wel effectief kunnen zijn. 


\section{Conclusies}

- Doorzaai in het najaar van 2016, 2017, 2018, of 2019 gaf respectievelijk gemiddeld 28, 30, 84, en 418 kiemplanten Engels raaigras per $\mathrm{m}^{2}$;

- $\quad$ Het vochtgehalte in de toplaag van de grond was doorslaggevend voor het aantal kiemplanten; in de eerste twee proefjaren waren de omstandigheden te droog of te nat voor een succesvolle doorzaai;

- Het grote aantal kiemplanten in 2019 was waarschijnlijk vooral het gevolg van het extra rollen van de doorgezaaide veldjes. Hierdoor werden de zaaisneden volledig gesloten en was de vochtvoorziening van de zaden maximaal;

- Doorzaai in 2016 of 2017 had geen effect op het aandeel Engels raaigras in de volgende jaren. Doorzaai in 2018 gaf in de zomer van 2019 op vier van de vijf percelen een gemiddeld 6,1 procentpunt (pp.) hoger aandeel Engels raaigras;

- Doorzaai in 2019 had geen effect op het aandeel Engels raaigras in 2020, waarschijnlijk als gevolg van de zware muizenschade in de voorgaande winter, waarbij de zode zwaar werd aangevreten. Wel leek het effect van doorzaai in 2018 in 2020 grotendeels in stand gebleven;

- In 2019 had het 6,1 pp. hogere aandeel Engels raaigras, als gevolg van doorzaaien in 2018, geen effect op de grasopbrengst;

- Het aandeel Engels raaigras in 2020, de grasopbrengst in 2019 en 2020, en de voederwaarde in 2020, werden niet beïnvloed door doorzaaien maar wel door voorbehandeling (kort afmaaien, eggen). Voorbehandeling heeft waarschijnlijk de muizenschade beperkt;

- Voorbehandeling in 2018 en 2019 gaf in 2019 en 2020 een 5-9\% hogere grasopbrengst, en in 2020 een $5 \%$ lager eiwitgehalte (vanwege een hogere opbrengst) en een $8 \%$ hoger suikergehalte. De VC-OS werd in 2020 niet beïnvloed;

- Voorbehandeling in 2016 en 2017 gaf in 2020 een 13\% hogere suikeropbrengst vergeleken met de controle. Dit effect was het gevolg van voorbehandeling en waarschijnlijk beperking van muizenschade, en werd vooral op perceel 2 gerealiseerd;

- Vervanging van 5-12 pp. ruw beemdgras door Engels raaigras had in 2020 geen effect op de grasopbrengst en voederwaarde;

- $\quad$ Spuiten tegen ruw beemdgras had, als aanvulling op eggen, vrijwel geen effect op het aantal kiemplanten Engels raaigras wanneer uitgevoerd onder voldoende droge omstandigheden, en had ook geen effect op de verhoging van het aandeel Engels raaigras in 2019 na doorzaaien in 2018. Eggen is daarmee voldoende effectief voor de bestrijding van ruw beemdgras;

- Voorbehandeling in 2018 had geen effect op het aandeel Engels raaigras of ruw beemdgras in de volgende zomer, hoewel in eerste instantie de zode opener werd en het aandeel ruw beemdgras afnam. De extra ruimte werd alleen door Engels raaigras ingenomen als er ook werd doorgezaaid, en anders opnieuw door ruw beemdgras;

- $\quad$ Op de onbehandelde veldjes van percelen 1, 3, en 4 nam tussen zomer van 2016 en 2019 het aandeel Engels raaigras significant toe, met respectievelijk gemiddeld 11,3, 7,0, en 7,7 pp. Hieruit blijkt dat het aandeel Engels raaigras ook door het type beheer kan worden verhoogd, in dit geval bemesten met alleen kunstmest, alleen maaien, en zwaar maaien van de eerste snede. 


\section{Betekenis voor de praktijk}

Wanneer is het zinvol om grasland met een goede bezetting, maar een afgenomen aandeel Engels raaigras, door te zaaien om het aandeel Engels raaigras te verhogen? Voor een zinvolle doorzaai is het van belang dat er:

1. voldoende kiemplanten opkomen;

2. deze resulteren in een duidelijk hoger aandeel Engels raaigras in het volgende seizoen, en;

3. dit hogere aandeel een voldoende toename geeft in grasopbrengst en/of voederwaarde.

Het voorliggende onderzoek laat zien dat het krijgen van voldoende kiemplanten geen probleem is, mits aan een aantal voorwaarden wordt voldaan (Bijlage). In de eerste twee jaren waren de omstandigheden bij doorzaai respectievelijk te droog (2016) of te nat (2017), en werden slechts 28 en 30 kiemplanten per $\mathrm{m}^{2}$ geteld. Deze aantallen leidden niet tot een toename van het aandeel Engels raaigras in het volgende seizoen. Bij doorzaai in 2018, met voldoende vocht in de grond maar onvoldoende sluiting van de zaaisneden, werden 84 kiemplanten per $\mathrm{m}^{2}$ geteld, wat in het volgende seizoen resulteerde in een 6 pp. hoger aandeel Engels raaigras. Na doorzaai in 2019, waarbij aan alle voorwaarden was voldaan, werden 418 kiemplanten per $\mathrm{m}^{2}$ geteld. Dit aantal had kunnen resulteren in een (veel) grotere toename van aandeel Engels raaigras dan na doorzaai in 2018, maar de zware muizenschade heeft conclusies daarover onmogelijk gemaakt. De inschatting op basis van alle resultaten is dat bij het voldoen aan de voorwaarden een toename in aandeel Engels raaigras van 10 pp. meestal haalbaar moet zijn in grasland waar ruw beemdgras de te vervangen grassoort is.

Bij opkomst van voldoende kiemplanten is van belang dat deze zich goed ontwikkelen tot volwassen planten. Bij doorzaai in september is het de vraag in hoeverre jonge planten de winter overleven. Afgezien van effecten van zware muizenvraat gaven onze resultaten niet de indruk dat jonge planten daar moeite mee hebben. Uit de opeenvolgende botanische karteringen blijkt dat het aandeel Engels raaigras tijdens de winter goed op peil kan blijven. Een voorbeeld is de winter van 2020 op 2021, waar een periode met relatief strenge vorst $\left(6 \mathrm{t} / \mathrm{m} 24\right.$ februari; minimum temperatuur $-15^{\circ} \mathrm{C}$ op 10 $\mathrm{cm}$ boven maaiveld; KNMI-station Leeuwarden) geen lager aandeel Engels raaigras gaf in het volgende voorjaar, vergeleken met de voorgaande zomer (Fig. 9 en 10).

Bij voldoende nieuwe planten in het volgende voorjaar is het vervolgens de vraag in hoeverre deze in de komende seizoenen bijdragen aan de grasopbrengst en -voederwaarde. Dit hangt in belangrijke mate af van de soorten grassen en kruiden die worden vervangen, en op welke grondsoort. Onze resultaten geven niet de indruk dat vervanging van 5-12 pp. ruw beemdgras door Engels raaigras een positief effect heeft op de grasopbrengst en/of voederwaarde van grasland op kleigrond. Mogelijk is er wel een positief effect bij een grotere vervanging, bij een 5-12 pp. vervanging op zandgrond, of bij weiden van het gras in plaats van maaien. Bij weiden in plaats van maaien worden de bruto grasopbrengst en/of voederwaarde zelf niet beïnvloed, maar kan selectie door de koe wel andere effecten op geven op de netto grasopname en melkopbrengst, vergeleken met stalvoeren van vers gras of van kuilgras.

De resultaten van het voorliggende onderzoek geven belangrijke informatie over vraatschade door veldmuizen en mogelijke maatregelen om deze schade te verminderen. De negatieve effecten van muizenvraat op aandeel Engels raaigras, opbrengst, en voederwaarde, waren duidelijk minder op veldjes die in voorgaande jaren waren geëgd. De waarschijnlijke oorzaak is dat door eggen een deel van de strooisellaag werd verwijderd, waardoor de muizen minder beschut waren tijdens de winter en de behandelde veldjes daarom meden. Onduidelijk is in hoeverre de muizen de mindere beschutting alleen als onaangenaam ervaren, of dat deze een negatief effect heeft op hun overleving. In het eerste geval zal het eggen van hele percelen waarschijnlijk minder of geen effect hebben, vergeleken met het eggen van de kleine veldjes in ons onderzoek, terwijl in het andere geval eggen op perceelniveau ook tot minder schade kan leiden. 


\section{Dankwoord}

Wij danken melkveehouder Oane Smink en Dairy Campus voor het ter beschikking stellen van de proefpercelen; de staf van Dairy Campus voor de proefuitvoer; Vredo Dodewaard B.V. voor het vier keer ter beschikking stellen van een Vredo Agri (Air) doorzaaimachine incl. ondersteuning; en Jan Rinze van der Schoot (Wageningen Plant Research) en Bert Philipsen (Wageningen Livestock Research) voor het reviewen van de conceptversie van dit rapport. Het onderzoek in dit rapport werd gefinancierd door het ministerie van LNV en het bedrijfsleven (www.ruwvoerenbodem.nl). 


\section{Referenties}

Anonymus (2016) Adviesbasis Bemesting Grasland en Voedergewassen, Wageningen Livestock Research, Wageningen

Bryant RH, Gregorini P, Edwards GR (2012) Effects of N fertilisation, leaf appearance and time of day on $\mathrm{N}$ fractionation and chemical composition of Lolium perenne cultivars in spring. Animal Feed Science and Technology 173:210-219

CVB (2021) CVB Feed Table 2021 - Chemical composition and nutritional values of feedstuffs. Foundation CVB, Venray, The Netherlands

De Boer HC, Deru JGC, Van Eekeren N (2018) Sward lifting in compacted grassland: effects on soil structure, grass rooting and productivity. Soil \& Tillage Research 184:317-325

Delagarde R, Peyraud JL, Delaby L, Faverdin P (2000) Vertical distribution of biomass, chemical composition and pepsin-cellulase digestibility in a perennial ryegrass sward: interaction with month of year, regrowth age and time of day. Animal Feed Science and Technology 84:49-68

Drewer J, Anderson M, Levy PE, Scholtes B, Helfter C, Parker J, Rees RM, Skiba UM (2017) The impact of ploughing intensively managed temperate grasslands on $\mathrm{N}_{2} \mathrm{O}, \mathrm{CH}_{4}$ and $\mathrm{CO}_{2}$ fluxes. Plant and Soil 411:193-208

Necpálová M, Li D, Lanigan G, Casey IA, Burchill W, Humphreys J (2014) Changes in soil organic carbon in a clay loam soil following ploughing and reseeding of permanent grassland under temperate moist climatic conditions. Grass and Forage Science 69:611-624

Shepherd MA, Hatch DJ, Jarvis SC, Bhogal A (2001) Nitrate leaching from reseeded pasture. Soil Use \& Management 17:97-105

Sikkema K (1997) Handleiding Beoordeling grasland- en slootvegetatie. Praktijkonderzoek Rundvee, Schapen en Paarden, Lelystad

Van Eekeren N, Bommelé L, Bloem J, Rutgers M, De Goede RGM, Reheul D, Brussaard L (2008) Soil biological quality after 36 years of ley-arable cropping, permanent grassland and permanent arable cropping. Applied Soil Ecology 40:432-446. 


\section{Bijlage}

\section{Aanbevelingen voor doorzaaien in de praktijk}

- Zaai bij voorkeur door rond half september. In deze periode neemt de concurrentiekracht van de bestaande graszode af als gevolg van de afnemende lichtinval, hebben de kiemplanten daardoor meer kans om zich te kunnen vestigen, en blijft de opbrengstderving van de bestaande zode beperkt. Verder neemt de kans op droogte steeds verder af, maar is de temperatuur nog wel voldoende hoog voor een vlotte ontwikkeling van de kiemplanten. Zaai niet meer door als de nachttemperatuur blijvend onder de 10 graden zakt;

- Zaai alleen door bij een voldoende vochtige (kneedbare) toplaag en, bij voorkeur, verwachting van neerslag in de twee weken na het doorzaaien. Wordt aan deze voorwaarden niet voldaan, stel het doorzaaien dan uit. Doorzaaien in een uitgedroogde of natte toplaag is niet zinvol;

- Zo kort mogelijk afmaaien van de zode voorafgaande aan het doorzaaien vermindert de (wortel)concurrentiekracht van de bestaande zode en maakt eggen makkelijker uitvoerbaar;

- Stop enkele weken voorafgaande aan het doorzaaien met stikstofbemesting, om de concurrentiekracht van de bestaande zode verder te verminderen;

- Krachtig eggen voorafgaande aan het doorzaaien, bij drogend weer, verwijdert onkruid, oppervlakkig wortelende grassen, en dood organisch materiaal uit de zode. Hiermee wordt extra ruimte voor kiemplanten gecreëerd;

- Gebruik bij het doorzaaien minimaal $15 \mathrm{~kg}$ goed kiemkrachtig zaad per ha, en zaai op een gemiddelde diepte van twee keer de zaadlengte. Meestal is dat $12-15 \mathrm{~mm}$;

- Zorg voor een correcte afstelling van de doorzaaimachine; zaai een teststrook en controleer (bij doorzaaien in sneden) de insnijding, de zaaidiepte, de zaadverdeling in de snede, en het sluiten van de sneden;

- Wanneer na het doorzaaien de toplaag te los is, of de zaaisneden niet volledig sluiten, rol dan na met een Cambridge-rol. Het aanduwen van de grond geeft een maximaal contact tussen de zaden en de grond en een maximale vochtvoorziening tijdens de kieming. 


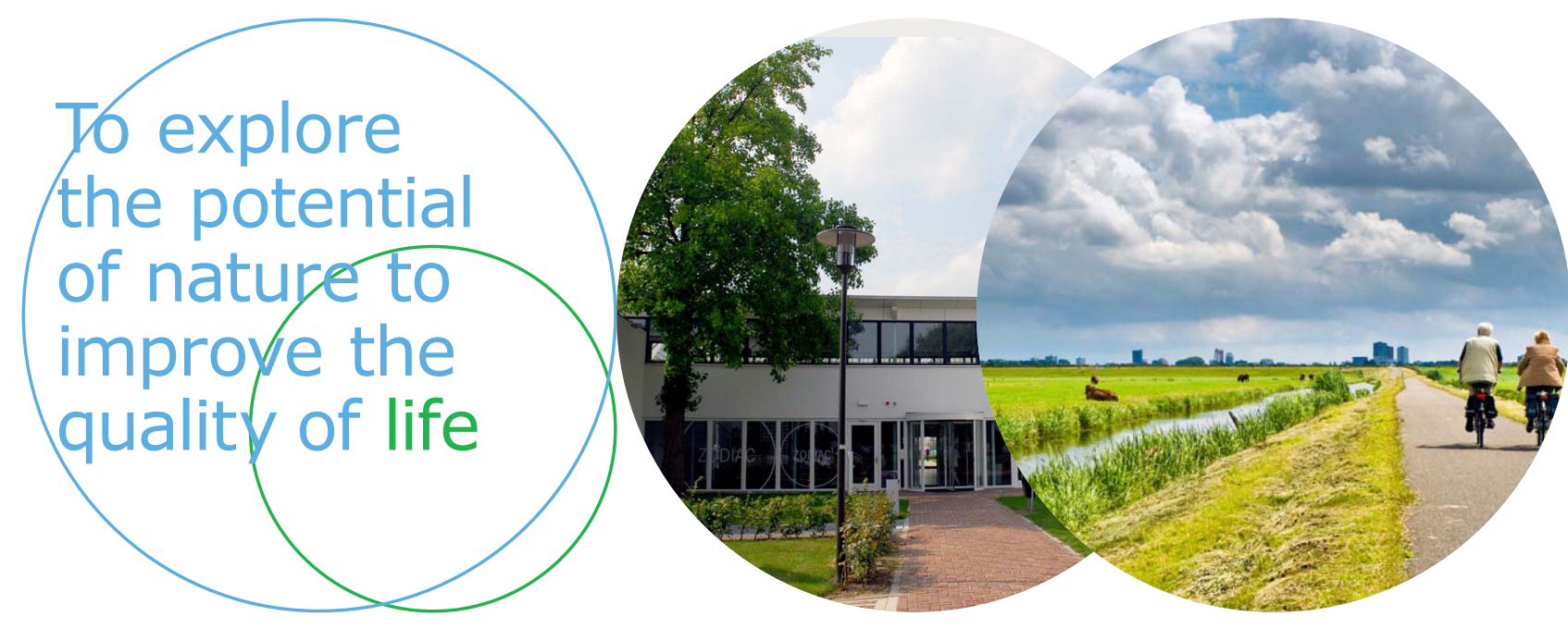

Wageningen Livestock Research Postbus 338

$6700 \mathrm{AH}$ Wageningen

T 0317483953

E info.livestockresearch@wur.nl www.wur.nl/livestock-research
Wageningen Livestock Research ontwikkelt kennis voor een zorgvuldige en renderende veehouderij, vertaalt deze naar praktijkgerichte oplossingen en innovaties, en zorgt voor doorstroming van deze kennis. Onze wetenschappelijke kennis op het gebied van veehouderijsystemen en van voeding, genetica, welzijn en milieu-impact van landbouwhuisdieren integreren we, samen met onze klanten, tot veehouderijconcepten voor de $21 \mathrm{e}$ eeuw.

De missie van Wageningen University \& Research is 'To explore the potential of nature to improve the quality of life'. Binnen Wageningen University \& Research bundelen 9 gespecialiseerde onderzoeksinstituten van Stichting Wageningen Research en Wageningen University hun krachten om bij te dragen aan de oplossing van belangrijke vragen in het domein van gezonde voeding en leefomgeving. Met ongeveer 30 vestigingen, 6.500 medewerkers en 10.000 studenten behoort Wageningen University \& Research wereldwijd tot de aansprekende kennisinstellingen binnen haar domein. De integrale benadering van de vraagstukken en de samenwerking tussen verschillende disciplines vormen het hart van de unieke Wageningen aanpak. 